\title{
Lithology and geochemical dispersal in till: Petitcodiac area, New Brunswick
}

\author{
B.E. Broster ${ }^{1}$, G.M. Allaby ${ }^{2}$, And A.G. Pronk ${ }^{3}$ \\ 1. Quaternary and Environmental Studies Group (QUEST), Department of Geology, University of New Brunswick, \\ P.O. Box 4400, Fredericton, New Brunswick E3B 5A3, Canada. \\ 2. Jacques Whitford, 20 Broadview Avenue South, Saint John, New Brunswick E2L 5C5, Canada. \\ 3. New Brunswick Department of Natural Resources, Minerals, Policy and planning Division, \\ P. O. Box 6000, Fredericton, New Brunswick E3B 5H1, Canada.
}

Date received: 16 December 2003 g Date accepted: 24 August 2004.

\begin{abstract}
Streamlined features, rat-tails, glacial striae, and dispersal patterns for till clasts and matrix geochemistry define glacier dynamics and flow directions across the Petitcodiac map area, southeastern New Brunswick. These data indicate that a single till sheet was deposited as the dominant ice-flow direction fluctuated between east, south-southwest, and east-southeast across the study area. The Anagance Ridges and Central Plateau formed major obstructions, but were eventually glaciated by southward flowing ice. Three phases of glacier flow are recognized:(1) an early topographicallycontrolled, thin-ice phase; (2) regional flow during a phase of maximum ice growth and; (3) a late phase of thinning ice. The late phase is characterized by: deviation of flow around major obstacles; ice-sheet drawdown toward outlets; flooding of low lying valleys due to eustatic rise in sea level; and glacier melting. No evidence was found indicating northward or radial flow from the Central Plateau.

Clast trains are traceable from known outcrops, southward over distances of $10 \mathrm{~km}$, whereas distinct till geochemical dispersal patterns are commonly lost within $5 \mathrm{~km}$ of transport from the known source unit. Geochemical dispersal suggests a potential for the identification of additional local mineralized zones along some faults.

Sand content in the till reflects increased erosion and incorporation at locations where the glacier climbed over major topographic obstacles, oriented transverse to the regional flow direction. The clay content increases primarily because of the incorporation of sediments occupying valleys and low-lying coastal areas at the time of glacier advance. These observations indicate that the basal sediment load did not establish an erosive equilibrium between the glacier and the underlying bedrock for all locations across the study area. Preferential incorporation occurred at points of increased erosion and in areas of thick preglacial sediment accumulations, altering matrix composition and obscuring some geochemical dispersal patterns. These observations have implications for glacial prospecting in sub-alpine terrains elsewhere.
\end{abstract}

\section{RÉSUMÉ}

Les caractéristiques laminaires, les queues-de-rat, les stries glaciaires et les traînées de dispersion des clastes de till de même que la composition géochimique de la matrice, définissent la dynamique du glacier et les directions de l'écoulement à l'intérieur du secteur cartographique de Petitcodiac, dans le Sud-Est du Nouveau-Brunswick. Ces données révèlent qu'une nappe de till unique s'est déposée pendant que la direction prédominante de l'écoulement des glaces fluctuait entre l'est, le sud-sud-est et l'est-sud-est dans le secteur d'étude. Les chaînons Anagance et le plateau Central ont constitué les principales obstructions, mais ils ont finalement été recouverts par des glaces s'écoulant vers le sud. On distingue trois phases d'écoulement glaciaire : 1) une phase précoce de glace mince topographiquement canalisée; 2) un écoulement régional au cours d'une phase de croissance maximale de la glace; et 3) une phase tardive d'amincissement de la glace. La phase tardive est caractérisée par une déviation de l'écoulement contournant les obstacles importants, un abaissement de la nappe glaciaire vers les décharges, une inondation des vallées basses par suite de la hausse eustatique du niveau de la mer et la fonte du glacier. Aucun indice révélant un écoulement vers le nord ou un écoulement radial à partir du plateau Central n'a été relevé

On peut retracer les traînées de clastes à partir des affleurements connus sur des distances de dix kilomètres en direction sud, tandis que les trains distincts de dispersion géochimique du till disparaissent à moins de cinq kilomètres de l'unité d'origine connue. La dispersion géochimique laisse supposer la possibilité qu'on découvre d'autres zones minéralisées locales le long de certaines failles. 
La teneur en sable du till témoigne d'une érosion et d'une incorporation accrues aux endroits où le glacier a franchi des obstacles topographiques importants orientés transversalement à la direction de l'écoulement régional. La teneur en argile s'accroît principalement en raison de l'incorporation de sédiments qui occupaient les vallées et les secteurs côtiers bas au moment de la progression du glacier. Ces observations révèlent que la charge solide basale n'a pas établi un équilibre d'érosion entre le glacier et le substrat rocheux sous-jacent à tous les emplacements à l'intérieur du secteur d'étude. Une incorporation plus poussée est survenue aux points d'érosion accrue et dans les secteurs d'accumulations préglaciaires épaisses de sédiments, ce qui a modifié la composition de la matrice et obscurci certains tracés de dispersion géochimique. Ces observations ont des répercussions pour la prospection glaciaire dans les terrains subalpins d'ailleurs.

[Traduit par la rédaction]

\section{INTRODUCTION}

From observations of striae and geomorphological features, Chalmers $(1890,1895)$ was first to report the occurrence of complex ice-flow patterns across New Brunswick, which he attributed to the interactions between local ice domes. Subsequent work by others (Grant 1977; Rampton et al. 1984; Hughes et al. 1985; Pronk et al. 1989; Rappol 1989) suggested that during the Late Wisconsinan an ice mass developed on the Appalachian Mountains in northwestern New Brunswick, blocking the southward movement of Laurentide ice into the province. This "Appalachian Ice Divide" may have allowed a regional ice system consisting of relatively small ice centres to develop in the Maritime Provinces.

Studies agree that, during the Late Wisconsinan, ice flow ranged from south-southeast to east in southeastern New Brunswick (Rampton and Paradis 1981; Rampton et al. 1984; Foisy and Prichonnet 1991; Seaman 1991; Munn et al. 1996). Shifts in flow direction occurred in response to fluctuations in the relative strengths of various local ice centres as glaciation progressed (Rampton et al. 1984). Refining the earlier work of Chalmers (1890), Rampton et al. (1984) divided the Late Wisconsinan glacial history of New Brunswick into six ice-flow "phases", primarily on cross-cutting striae relationships, that are loosely constrained by ${ }^{14} \mathrm{C}$ radiometric-dating.

In southeastern New Brunswick, glaciation of the Central Plateau (Fig. 1) was thought to have occurred early, while the Plateau may have been a nunatak during the Late Wisconsinan (Rampton et al. 1984). By correlating local till deposits north and south of the Caledonia Highlands, Foisy and Prichonnet (1991) demonstrated that the area, including the Central Plateau, was glaciated during the Late Wisconsinan. These authors proposed that a shrinking local ice cap with radial outflow was in existence during glaciation of this area.

From a compilation of published striae data for New Brunswick (Seaman 1989), it is apparent that south-southeast directions are dominant in the study area, although east-west trending striae and some northward flow indicators have been reported to occur in adjacent map sheets (e.g. Foisy and Prichonnet 1991). South of the study area, an occurrence of northwestward directed striae (toward $300^{\circ}$ ) was reported by Seaman (1989). Also, rare north-northwest directed rat tails on the northern flanks of the highlands, and distinctive felsic and mafic till clasts found north of their original (Precambrian) source area, have been cited as evidence of northward flowing glaciers during the Early Wisconsinan (Foisy and Prichonnet 1991). However, recent research south of the study area by Broster et al. (1997) suggests that the Precambrian lithologies have undergone multiple (pre-Carboniferous) erosive and transport events and are present as clasts and boulders within the younger Carboniferous conglomerate units. These underlying conglomerate units were a second source of clast lithologies, originally from surrounding Precambrian bedrock units, and not considered definitive evidence of northward glacier transport (Broster et al. 1997).

The study area is ideally located to further evaluate if, during the Late Wisconsinan, the Central Plateau was a nunatak or was covered by an ice mass experiencing radial flow. In addition, distinctive lithologies in the underlying bedrock enable examination of till dispersal patterns for additional evidence of northward flow.

\section{LOCATION, PHYSIOGRAPHY \& BEDROCK GEOLOGY}

The Petitcodiac map area (National Topographic Series $21 \mathrm{H} / 14$, scale $1: 50000$ ) is located in southeastern New Brunswick, midway between the municipalities of Moncton and Sussex (Fig. 1), and encompasses approximately $1092 \mathrm{~km}^{2}$. It lies within the Caledonian Highlands physiographic unit, a subdivision of the New Brunswick Highlands (Bostock 1970; Rampton et al. 1984). The study area can be further subdivided into two units based on geology and geomorphology: (a) the Anagance Ridges comprising folded and faulted Carboniferous sedimentary strata and metamorphic rocks, and (b) the Central Plateau (Fig. 1) locally composed mainly of Late Hadrynian granitic igneous rocks (McLeod et al. 1994). The Carboniferous / Hadrynian lithologic boundary (Fig. 2) between the two physiographic areas provides a clear datum to assess local glacial dispersal (Broster et al. 1997). Several mineral occurrences (Rose and Johnson 1990) and some distinctive lithologies provide "point-source" targets for delineation of dispersal trains. Only a cursory review of the major bedrock units and mineral occurrences will be discussed herein.

\section{The Anagance Ridges}

The Anagance Ridges area is characterized by northeastsouthwest ridge and valley topography (Rampton and Paradis 


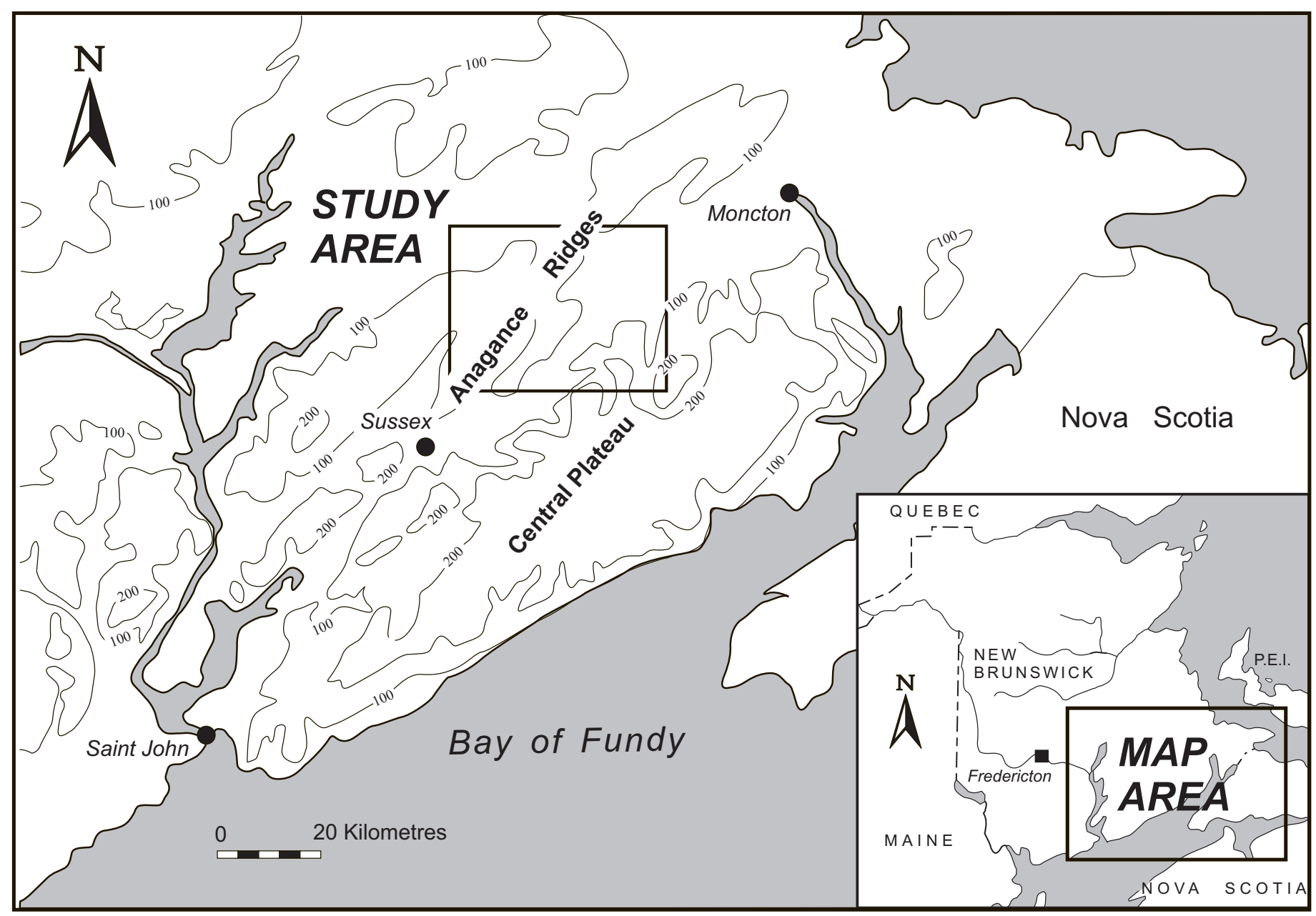

Fig. 1 Location of study area: physiographic regions after Rampton et al. (1984).

1981) and constitutes about $90 \%$ of the study area. Major topographical features parallel northeastward-southwestward oriented local faults and bedrock contacts, with relief ranging from 100 to $200 \mathrm{~m}$. In the southeastern corner of the map sheet, the topography becomes increasingly hilly where glacially streamlined ridges rise $120 \mathrm{~m}$ to $250 \mathrm{~m}$ above the valley floors. In contrast, the northern regions exhibit much less topographic expression, having a gently undulating plateaulike surface interrupted by occasional clusters of rolling hills (Rampton and Paradis 1981; Seaman 1987). In the northeast, the terrain grades to a gently undulating surface and lies below an elevation of $75 \mathrm{~m}$ as it encompasses a small part of the Moncton Sub-basin.

Bedrock contacts are not well constrained due to poor exposure throughout most of the Petitcodiac map area. Mapped bedrock units range from Precambrian to Late Carboniferous in age, but Carboniferous marine and terrestrial sedimentary rocks underlie most of the study region (Fig. 2). The larger units consist of Paleozoic sedimentary rocks. The dominant local lithologies include: polymictic conglomerate, sandstone, arkosic sandstone, siltstone, and shale, with rare limestone and gypsum. Munn et al. (1996) reported that the conglomerate units contain rare clasts of extrusive lithologies and lesser amounts of granite, granodiorite and diorite clasts, derived from Caledonia Zone source rocks to the south (van de Poll 1994).

\section{The Central Plateau}

The Central Plateau is located in the southeastern corner of the study area (Fig. 1). Here, the elevation rises from 160 to $325 \mathrm{~m}$ along the edge of the plateau. The plateau contains small hills typically 30 to $90 \mathrm{~m}$ in relief and slopes gradually toward the southwest.

Igneous units and rare sedimentary strata outcrop in this area and form part of the Caledonia Zone (Fig. 2). The igneous units are mainly rocks of the late Hadrynian Point Wolfe River Pluton, consisting of a variety of folded and faulted felsic and mafic volcanic (rock) units with interbedded sedimentary rocks that are intruded by Cambrian granodiorite, coarse granites, diorite and minor gabbro and rhyolite lithologies (Ruitenberg et al. 1979; Barr and White 1988). These rocks are intensely sheared in some outcrops. A much smaller occurrence of rock with similar lithologies is also found along the western edge of 


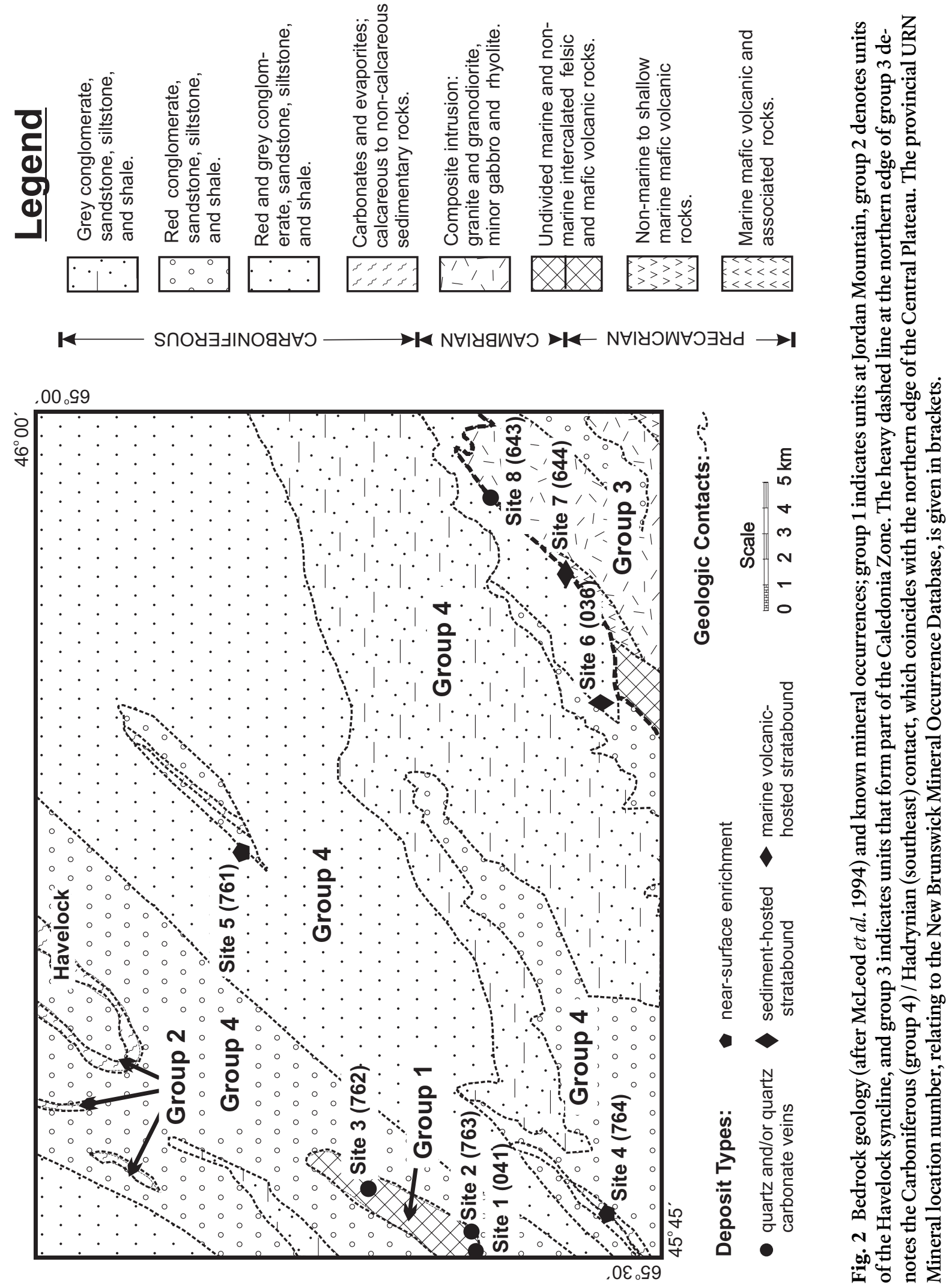


the map area at Jordan Mountain, where Cambrian basement rock outcrops (Fig. 2).

\section{Mineral occurrences}

The majority of the mineral exploration in the study area was conducted in the 1970s and 1980s. Presently there are no base metal deposits of economic interest, but there is an active limestone quarry located at Havelock containing subeconomic gypsum deposits (Fig. 2). St. Peter (1992) suggested that cupriferous deposits in the Carboniferous strata may be genetically related to faults in the southeastern section of the Moncton Sub-basin (located in the northeastern corner of the study area).

Eight individual base metal occurrences have been identified in the study area (Fig. 2) that may be useful as "point sources" for glacial dispersal. Several mineralized occurrences are associated with the Jordan Mountain area (Sites 1-4, Fig. 2). Site 1 (Fig. 2) represents a base metal occurrence associated with a shear zone in a massive rhyolite host rock containing: chalcocite, malachite, silver, and gold (Rose and Johnson 1990; Merlini 1998). The shear zone is 3-4 m wide and approximately $210 \mathrm{~m}$ long. Mineralization is disseminated in the rhyolite host rock and is concentrated along irregular seams. Site 2 (Fig. 2) at Jordan Mountain contains manganite intergrown with pyrolusite, and reduced amounts of hausmannite and psilomelane (Rose and Johnson 1990; Merlini 1998). This near-surface mineralization is found in massive lenses, blebs, and stringers in the cement of a Lower Carboniferous Hillsborough Formation conglomerate unit.

Approximately $4 \mathrm{~km}$ northeast of Jordan Mountain, at site 3 (Fig. 2), lenticular quartz veins containing sulphide and gold occur in a $23 \mathrm{~m}$ long, $10 \mathrm{~m}$ wide zone, cutting dark grey quartzose slate (Rose and Johnson 1990; Merlini 1998). South of Jordan Mountain at site 4 (Fig. 2), disseminated chalcocite and malachite occur in the matrix of a grey conglomerate overlain by red sandstone, red conglomerate, and Windsor Group limestone (Rose and Johnson 1990; Merlini 1998). The mineralized zone here is less than $30 \mathrm{~cm}$ thick. A second zone of mineralization, similar to site 4, occurs at site 5 (Fig. 2) in the central part of the study area (Rose and Johnson 1990; Merlini 1998).

Three sites of mineralization occur in close proximity at the southeastern corner of the study area. At site 6 (Fig. 2), primary and secondary minerals occur in a fanglomerate matrix, as coatings on the pebbles and as infillings of fractures and cavities (Rose and Johnson 1990; Merlini 1998). Additional smaller occurrences are found locally. These shallow sub-economic occurrences contain manganese oxides, covellite, chalcopyrite, malachite, azurite, copper, and silver (Rose and Johnson 1990; Merlini 1998). In the Precambrian Coldbrook Group at Site 7 (Fig. 2), felsic tuffs contain lenses of quartz and carbonate, hosting disseminated zinc and copper sulphides along with traces of gold, within schistose zones demonstrating intense drag-folding (Rose and Johnson 1990; Merlini 1998). At Site 8 (Fig. 2), a large tabular body of fault breccia is composed of felsic rock cemented by manganese oxides and containing massive botryoidal psilomelane and braunite, as well as crystals and needles of manganite in vugs with barite. Mineralization extends over an outcrop of approximately $1 \mathrm{~m}$ in width by 60 m wide (Rose and Johnson 1990; Merlini 1998).

\section{Surficial geology}

The absence of datable surficial sediments and the insufficient number of stratigraphic exposures have limited surficial studies in the study area. Brief descriptions of the local soils and surficial geology are found in a soil survey report for southeastern New Brunswick (Aalund and Wicklund 1950). Additional information is found in regional mapping projects of the surficial geology of New Brunswick (Chalmers 1890; Rampton et al. 1984), and in a compilation of all published glacial striae data for New Brunswick (Seaman 1989).

In southeastern New Brunswick, the regional ice-flow direction during the Late Wisconsinan ranged between southsouthwest and southeast (Rampton et al. 1984; Munn et al. 1996; Broster et al. 1997). Within the Petitcodiac map area, similar ice-flow directions have been documented (Chalmers 1890; Rampton et al. 1984; Seaman 1987, 1991). However, in the eastern part of the map area, Chalmers (1890) reported striae and grooves indicative of northeastward ice-flow. His observations were refuted by Rampton et al. (1984), but have since gained support from discovery of similar striae orientations at a site immediately east of the Petitcodiac map area (Foisy and Prichonnet 1991).

Mapping by Seaman (1987) revealed that, in the western half of the study area, ice movement was generally southward. Seaman (1987) further suggested that moraine and extensive ice-contact deposits along the sides of the Kennebecasis River valley record the positions of ice margins that were relatively stable for a long time.

\section{SAMPLE ANALYSES AND STATISTICS}

Fieldwork was conducted in southeastern New Brunswick on the Petitcodiac map area (NTS 21H/14, Fig. 3) during the summers of 1997 and 1998 as part of a regional surficial mapping project of the New Brunswick Department of Natural Resources and Energy. A single till sheet was found, although its colour and composition changes with variations in underlying bedrock. Till samples were collected using a $2 \mathrm{~km}$ grid spacing from natural exposures and hand-excavated pits (Fig. 3). Sample pits were generally $0.5 \mathrm{~m}$ in diameter and were dug to a depth sufficient to penetrate the C-horizon. Unweathered basal till (sensu stricto Dreimanis 1976) was the preferred material, although ablation till may have been (unavoidably) sampled at some localities. In southern New Brunswick, ablation till is commonly derived from local sources resulting in a geochemical signature similar to that of basal till (Seaman 1992; Stumpf et al 1997).

A total of 270 samples were collected (Fig. 3) for grain size, 


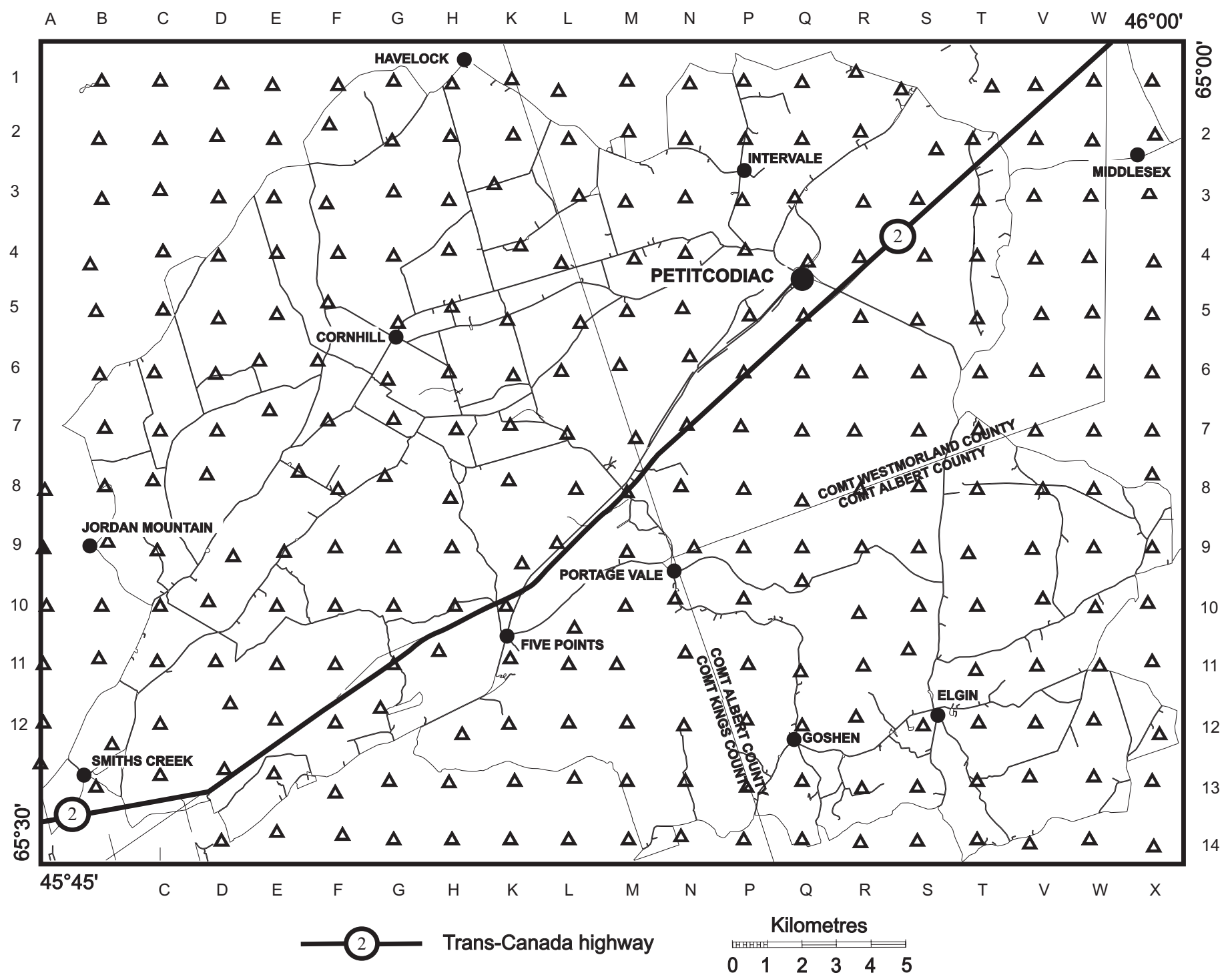

Fig. 3 Location of sample sites (triangles) in the Petitcodiac map area $(21 \mathrm{H} / 14)$ with major municipalities and highways.

clast identification and geochemical analyses. The lithologies of 50 to 100 clasts ( $>2.5 \mathrm{~cm}$ in diameter) were identified for each sample location and compared to representative suites of the major bedrock units in the area. Clast identification was conducted on unweathered surfaces using a hand lens and occasional optical examinations of thin sections (Allaby 2000). The relative proportions of sand, silt, and clay in the sample were determined according to the modified hydrometer method (Bouyoucos 1962). Geochemical analysis of the < $0.063 \mathrm{~mm}$ fraction collected from the till matrix was performed by Activation Laboratories Limited (ACTLABS) for 48 base metal, trace, and rare earth elements (Allaby 2000). However, the results for only a few of these elements will be discussed here as they represent some of the larger concentrations, best dispersal patterns, and are associated with the mineralized sites. Base metal concentrations were determined by Inductively
Coupled Plasma Emission Spectrometry (ICP-ES). Trace and rare earth element concentrations were obtained using Instrumental Neutron Activation Analysis (INAA). Anomalous element concentrations are equivalent to the upper $2.5 \%$ of the data range (after Hawkes and Webb 1962). Standards and sample splits were included with the sample suite to evaluate the precision and accuracy of the geochemical analysis (Allaby 2000).

Spatial distributions of component abundances were plotted using Surfer ${ }^{\circledR} 6.01$ computer software. A kriging geostatistical treatment of the data was performed to extrapolate unbiased contours between data points. Version 8 of the Statistical Package for the Social Sciences (SPSS 8.0 for Windows ${ }^{\circledR}$ ) was used to examine covariance among granulometric, lithological, and geochemical data by Spearman's rank correlation analysis. 


\section{OBSERVATIONS AND INTERPRETATIONS}

Till blankets most of the bedrock in the Petitcodiac area. Basal till (sensu stricto; Dreimanis 1976) was the most common glacial sediment encountered. Only one stratigraphic unit of till was observed during fieldwork. The average thickness of till ranged from $0.5 \mathrm{~m}$ to $2 \mathrm{~m}$ and was found to be highly variable in colour, texture, and compactness. Till compaction, texture, and colour were closely related to the parent material.

\section{Striae and streamlined directional features}

In the eastern half of the study area, striae indicate that the dominant ice-flow direction varied between south-southwest and southeast, similar to that reported locally by others (Rampton et al. 1984; Seaman 1989; Munn et al. 1996). Multiple directions were recorded at two sites in the northeastern corner of the study area. Cross-cutting relationships demonstrate directions, from youngest to oldest: (1) $150^{\circ}-170^{\circ}$, (2) $095^{\circ}-105^{\circ}$, (3) $070^{\circ}-090^{\circ},(4) 060^{\circ}-040^{\circ}$ (Fig. 4). These striae sets may record a gradual counter-clockwise shift in ice-flow from the south toward the northeast during expansion of the "Gaspereau Ice Centre", proposed to have been located to the west of our study area (Rampton et al. 1984). However, some eastward readjustment of late-glacial flow should be expected because of flow into the Gulf of St. Lawrence and subsequent drawdown of ice toward that location.

At the southeast corner, striae sites at higher elevations along the edge of the Central Plateau(Fig. 4) record mainly the south-southwest to southeasterly ice movement. Rare northeastward-southwestward directed striae occur in some valleys, possibly due to early ice-flow around this higher plateau. No evidence of the late phase eastward, northeastward or northwestward ice-flow was found on the plateau, suggesting:(a) that ice did not flow radially off this part of the Central Plateau; and (b) that any northeastward flow affected mainly the northern part of the study area. Streamlined bedrock features found in the western part of the study area indicate that ice flowed both southwestward and northeastward around the Anagance Ridges (Fig. 4). The diversion of ice flow around ridges of $<200$ $m$ in elevation indicates an erosive eastward ice-flow event that was likely due to thin ice flowing under topographic control or

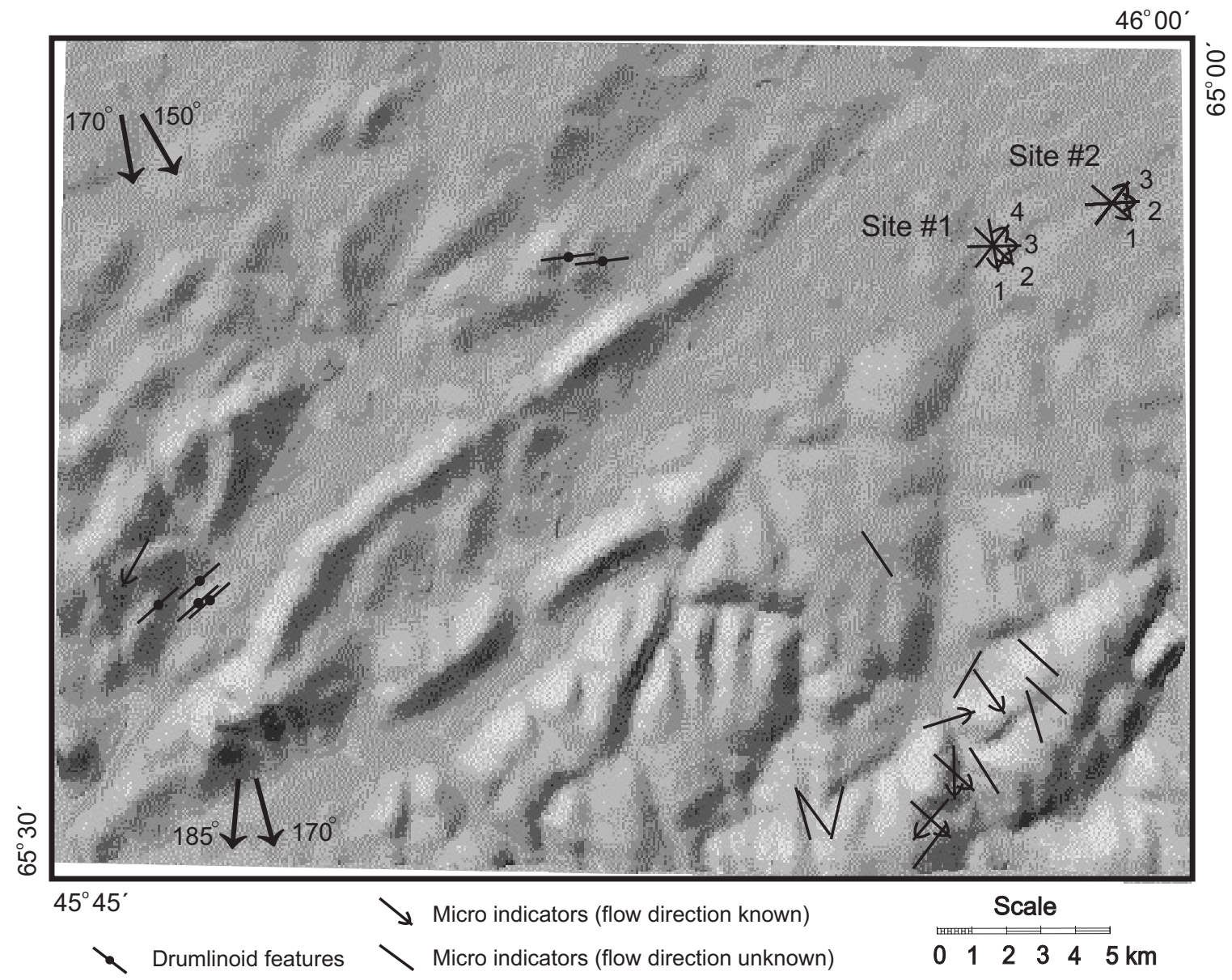

Fig. 4 Micro ice-flow indicators (e.g. striae, rat tails) and orientations of streamlined landforms, superimposed on shaded elevation image using a Digital Terrain Model (DTM). Chronology of striae at site 1 are given from oldest (1) to youngest (4) as discussed herein. The main directions of regional ice movement along the western side of the study area are indicated by the large arrows. 
the result of other influences (e.g. ice growth to the northwest, or ice drainage to the east). However, in the southwestern part of the study area, drumlinoid features and striae imply southwesterly ice movement during the major flow event.

\section{Pebble lithologies and covariance}

Correlation coefficients $\left(\mathrm{r}_{\mathrm{s}}\right)$ with absolute values greater than 0.599 , that is greater than a $35.9 \%$ correlation between the data (Silk 1979), are considered indicative of a significant association between the variables, and will be the main values discussed (Table 1). No significant correlations were found between the clast lithology and matrix data. However, a moderate positive relationship (0.589) was found between concentrations of clasts derived from felsic extrusive and intrusive bedrock.

Spatial dispersal of till clasts was examined by measuring the relative abundance (i.e. percentage) of the major indicator lithologies at each sample site. The major lithologies are granitic (igneous and metamorphic), felsic volcanic, felsic tuffs, mafic volcanic, red and grey conglomerates, and sandstones. Of significance, Lower Carboniferous limestone, gypsum, and anhydrite occur in the Havelock syncline (Fig. 2), with multiple smaller units outcropping along faults (McLeod et al. 1994). To facilitate discussion of clast dispersal, the lithologies can be grouped into four main categories: (a) sedimentary rocks that underlie most of the study area; (b) felsic and mafic volcanic rocks that occur in association with (c) granitic rocks of the Central Plateau and parts of the Jordan Mountain anticline; and (d) evaporite bedrock units that are associated with the Havelock syncline (Fig. 2). However, evaporite clasts were not found in the sample collections suggesting that they did not survive any appreciable transport distance.

The complex stratigraphy of the Carboniferous sedimentary rock units in the area has not been established in detail, making it difficult to interpret glacial dispersal of till clasts from sedimentary bedrock sources. Clasts derived from sedimentary rock units are red or grey conglomerates, sandstones, and mudstones/siltstones. Concentrations of clasts with sedimentary rock lithologies are the highest in the till overlying the central area (100\%) and decrease south-southeastward of the Carboniferous / Hadrynian boundary (Fig. 5) as the underlying bedrock changes, from mostly sedimentary units in the north to predominantly igneous units in the south.

In contrast to the clasts derived from sedimentary bedrock, granitic clasts, derived from granite and granodiorite, increase in concentration toward the south-southeast, from less than $5 \%$ to greater than $50 \%$ over a distance of $5 \mathrm{~km}$ from the Carboniferous / Hadrynian boundary (Fig. 6). Granitic clasts form south-southeast and south-southwestward oriented dispersal patterns originating from an unidentified source at the northern edge of the study area (Fig. 6). The dispersal patterns suggest possible dispersal of granitic clasts over a distance of 16 $\mathrm{km}$, but the pattern likely represents entrainment from multiple sources of granite/granodiorite clast-rich zones within the underlying conglomerate (Broster et al. 1997). Granitic clast dispersal forms a large (>90\%) "bulls eye" pattern overlying the Jordan Mountain anticline (Fig. 6), although this pattern may continue in a southeastward direction beyond the study area.

Clasts of an immature porphyritic felsic volcanic lithology were observed during fieldwork, in Windsor Group conglomerate outcropping near the base of Jordan Mountain (Fig. 2). Felsic and mafic volcanic clasts have been reported in the Hopewell Conglomerate (van de Poll 1994) and were discovered in Horton Group conglomerate during our investigation of the northern area of Jordan Mountain. The anomalous concentrations of clasts of felsic volcanic origin in the northern part of the area are probably derived from the underlying conglomerate units (Broster et al. 1997). The longest dispersal train occurs at the northern area of the Jordan Mountain rocks (Fig. 7) and extends eastward about $5 \mathrm{~km}$ and southeastward over approximately $10 \mathrm{~km}$. Here the concentrations are as high as $70 \%$ and felsic rock units underlie some parts of the Jordan Mountain area. However, other "bulls eye" occurrences of felsic volcanic clasts in till overlying the Hopewell Group are probably derived from local conglomerate units. In the southeast corner of the study area (Fig. 7), the concentration of till clasts derived from felsic volcanic rock increases southward across the Carboniferous / Hadrynian boundary (Fig. 7). Clasts of felsic volcanic origin occur rarely in till immediately northwest of this boundary, which does not support the possibility of northward radial ice-flow from the Central Plateau suggested by Foisy and Prichonnet (1991).

Felsic tuffs and mafic volcanic rocks are found south of the Carboniferous / Hadrynian boundary, at Jordan Mountain, and north-northwest of our study area (Fig. 7). These data demonstrate three patterns that were also seen in other clasts and geochemical patterns discussed below. For example, south of the Carboniferous / Hadrynian boundary and at Jordan Mountain, many dispersal patterns extend southward for approximately $5 \mathrm{~km}$ and eastward for 1-2 km. In the northwestern corner of the map area, felsic tuff erratics produce a dispersal train $10 \mathrm{~km}$ long, elongated southward (Fig. 7) accompanied by a large occurrence of mafic volcanic clasts. There are no mapped felsic tuff or mafic volcanic units in the immediate vicinity of the erratics, but the shape of their dispersal train suggests that a bedrock source is located at the northeastern limits of the study area.

\section{Matrix granulometric distribution and covariance}

In the granulometric data, sand and clay content demonstrate a strong negative correlation $(-0.845)$ that may be due to closure. "Closure" is one type of false correlation that can occur when examining correlations among grouped variables that sum to a fixed total (Broster 1982). However, it is also possible that this correlation may be partially reflecting the process of comminution of sand to clay-sized fragments or some other glacidynamic process. These observations are also relevant to the strong negative correlation $(-0.815)$ between the sand and silt content (Table 1). However, in both the geochemical and 


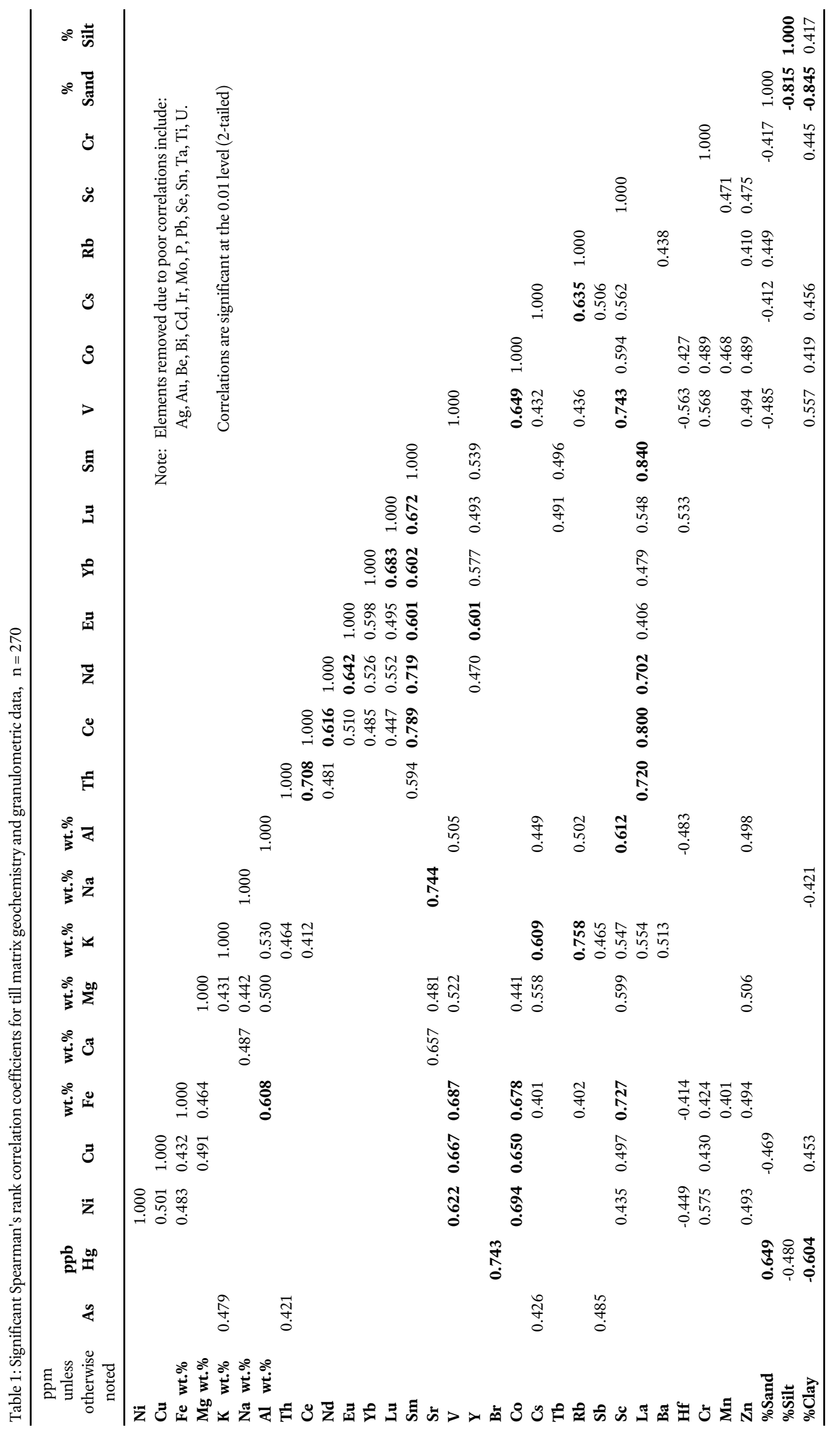


Fig. 5 Percent of till clasts derived from sedimentary bedrock units. The shaded areas indicate known igneous rock units and dashed lines indicate major faults (see Fig. 2).
Fig. 6 Percent abundance of granitic till (granite/ granodiorite) clasts. The shaded areas indicate granite and granodiorite rock units and dashed lines indicate major faults (see Fig. 2).

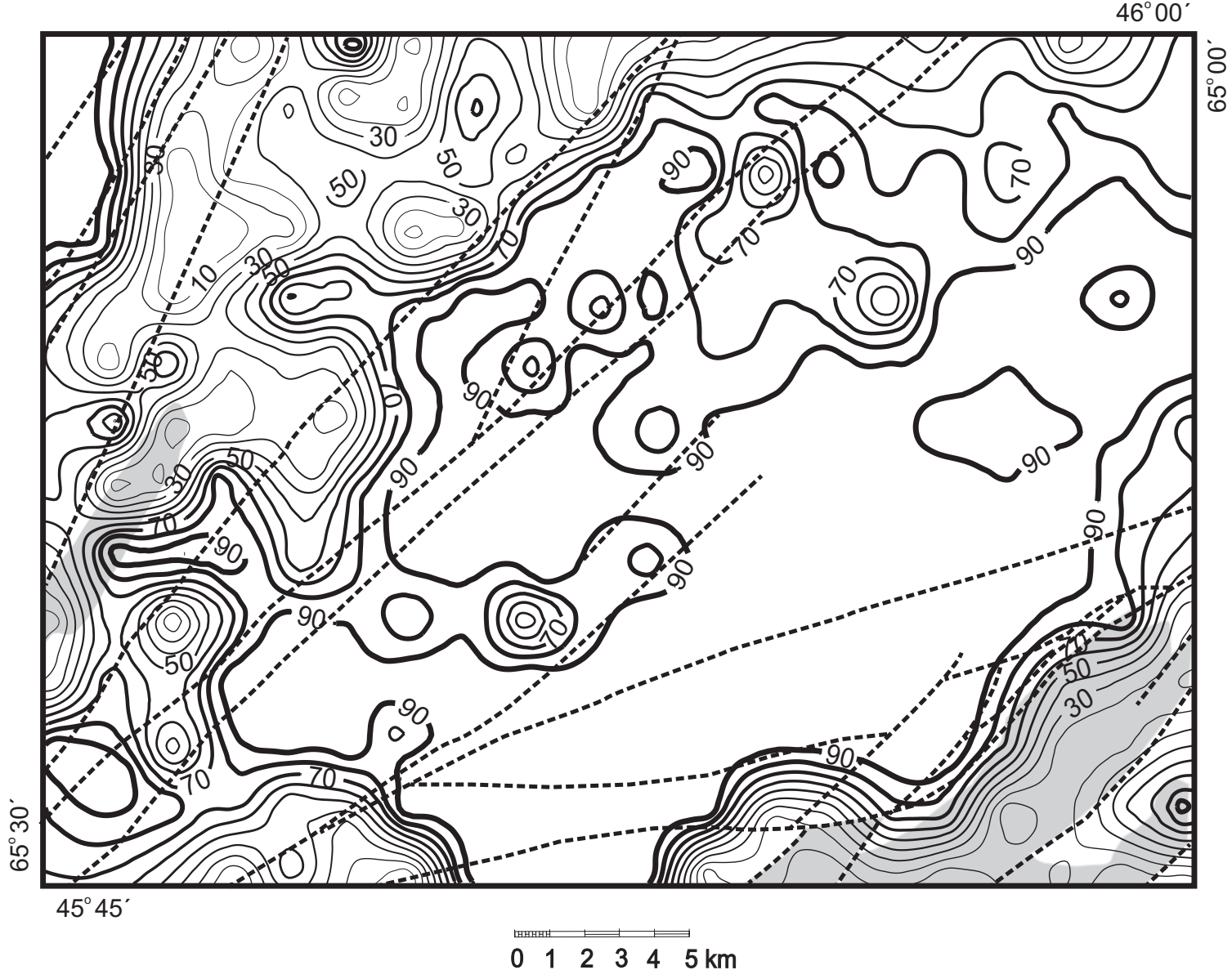

$46^{\circ} 00^{\prime}$

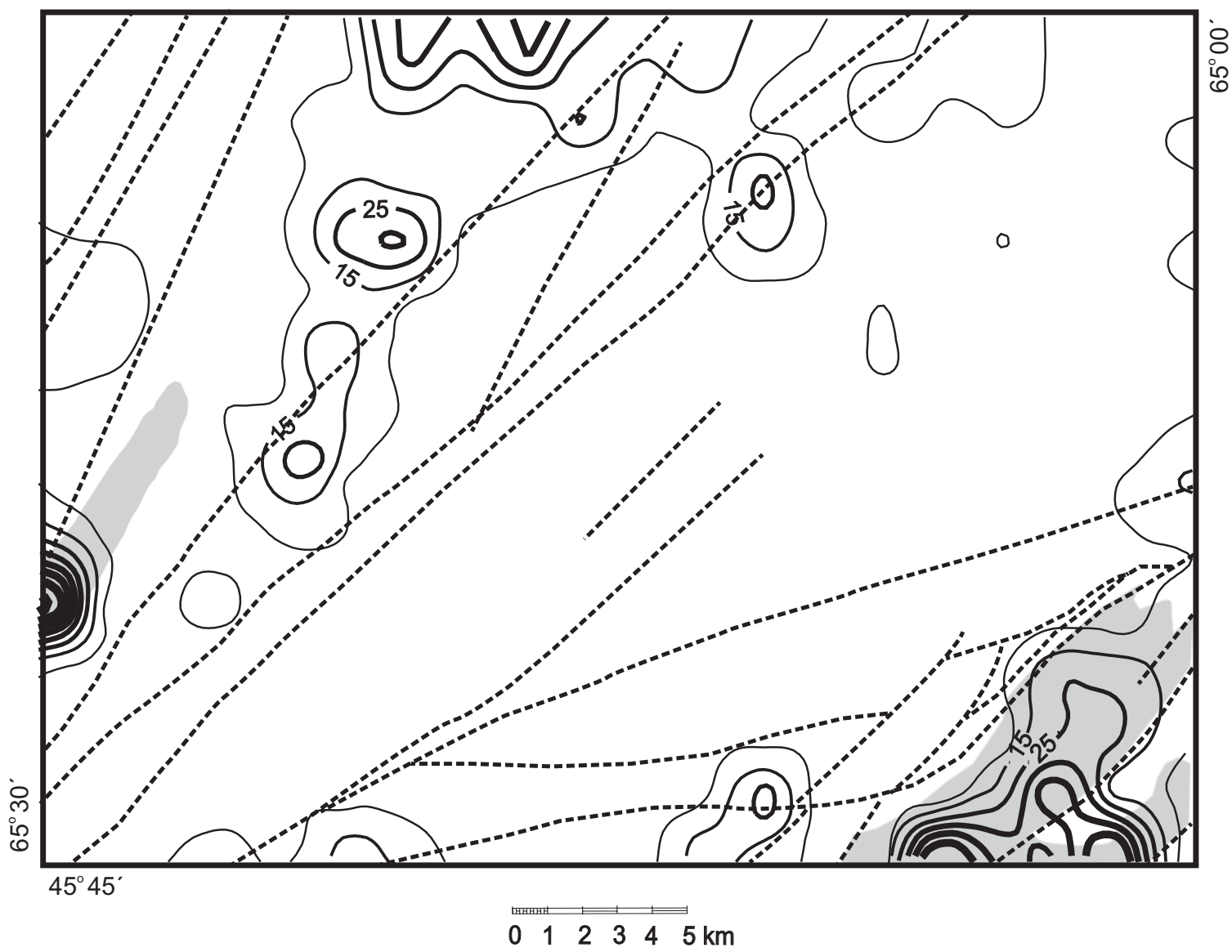


clast lithology data, the magnitude of the closure effect is less significant due to the larger number of variables involved in their fixed total (Broster 1982).

Similar to other locations across southern New Brunswick (Balzer and Broster 1994; Hornibrook et al. 1991; Munn et al. 1996; Stumpf et al. 1997), the texture and composition of till in the study area changes with variation in underlying lithology and topography. This is most noticeable when percent grainsize is contoured and examined relative to a digital topographic model of surface relief. For example, sand-rich areas are coincident with ridges and hilly areas (Fig. 8), and clay content is coincident with topographic lows such as in the northeast of our area (Fig. 9). For the most part, the clay likely represents pre-glacial accumulations contained in low-lying areas that were incorporated during ice advance. Conversely, increased stresses on the stoss side of obstacles, as the glacier climbed over bedrock obstructions, likely facilitated comminution and thrusting within the glacier, resulting in the preferential increase in sand and the coarse fraction of the till, down ice of major topographic obstructions.

\section{Matrix geochemistry and covariance}

Element concentrations in the till were contoured to enable recognition of dispersal patterns of anomalies and allow comparisons between spatial distribution of elements.
"Anomalous" concentrations are defined as the upper $95.44^{\text {th }}$ percentile of element distributions, including values outside two standard deviations from the median. Geochemical covariance is presented in Table 1 for the significant relationships among the 48 elements analyzed, although only a few will be discussed here.

Geochemical dispersal patterns in the till matrix were relatively short $(2-6 \mathrm{~km})$ and irregular, similar to those described by Balzer and Broster (1994), Munn et al. (1996), and Stumpf et al. (1997) for other areas of southern New Brunswick. The lengths of the dispersal trains were observed to be related to topography. Sources located in topographic lows oriented transverse to ice flow, generally display little down-ice glacial dispersion. Conversely, sources on topographic highs or ridges produce longer dispersal trains, previously reported by Hornibrook et al. (1991).

For many elements (e.g. Au, Be, Eu, Ir, Mo, Tb, U), matrix concentrations rarely exceed background levels. A few elements display isolated concentrations ("bulls-eye" patterns), possibly associated with local faults (Allaby 2000), but with no apparent down-ice elongated dispersal fan. For many elements, the highest till concentrations occur near, or down ice of, known mineral occurrences, overlying specific rock types or parallel to local structural trends. For example, seven rare earth elements (Ce, $\mathrm{Eu}, \mathrm{Lu}, \mathrm{Nd}, \mathrm{Sm}, \mathrm{Tb}$, and $\mathrm{Yb}$ ) were examined and the major anomalous till concentrations (Allaby 2000) are associated with

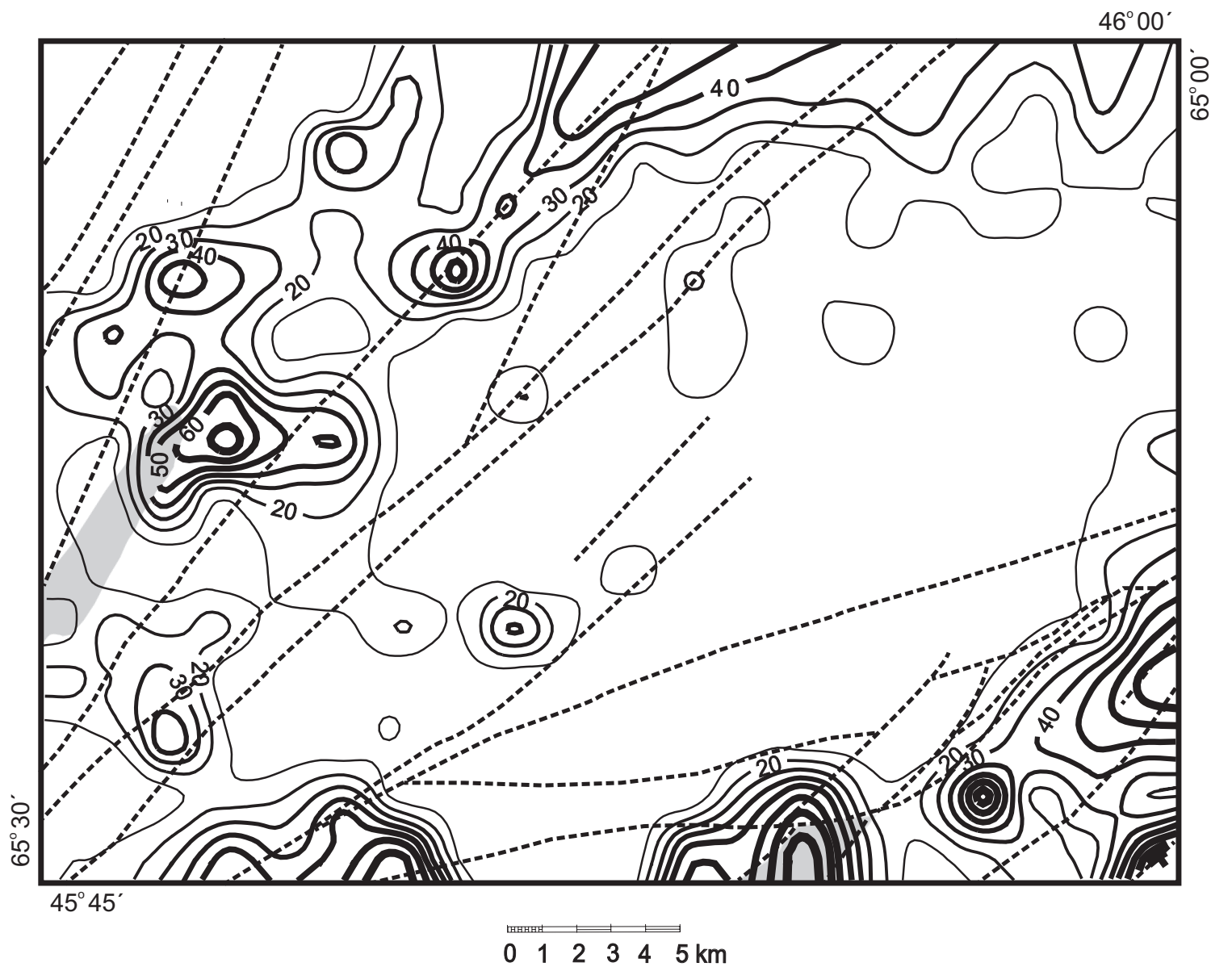

Fig. 7 Percent of felsic volcanic till clasts. The shaded areas denotes mapped areas of this lithology and dashed lines indicate major faults (see Fig. 2). 
Fig. 8 Contoured percent sand abundance in till matrix, superimposed on shaded DTM. Note higher concentrations of sand at locations parallel to and down-glacier of the areas of rugged terrain and oblique to the regional ice flow direction (see Fig. 4)

Fig. 9 Contoured percent clay abundance in till matrix superimposed on shaded DTM. Note higher concentrations of clay in areas at or down-glacier of major valleys.

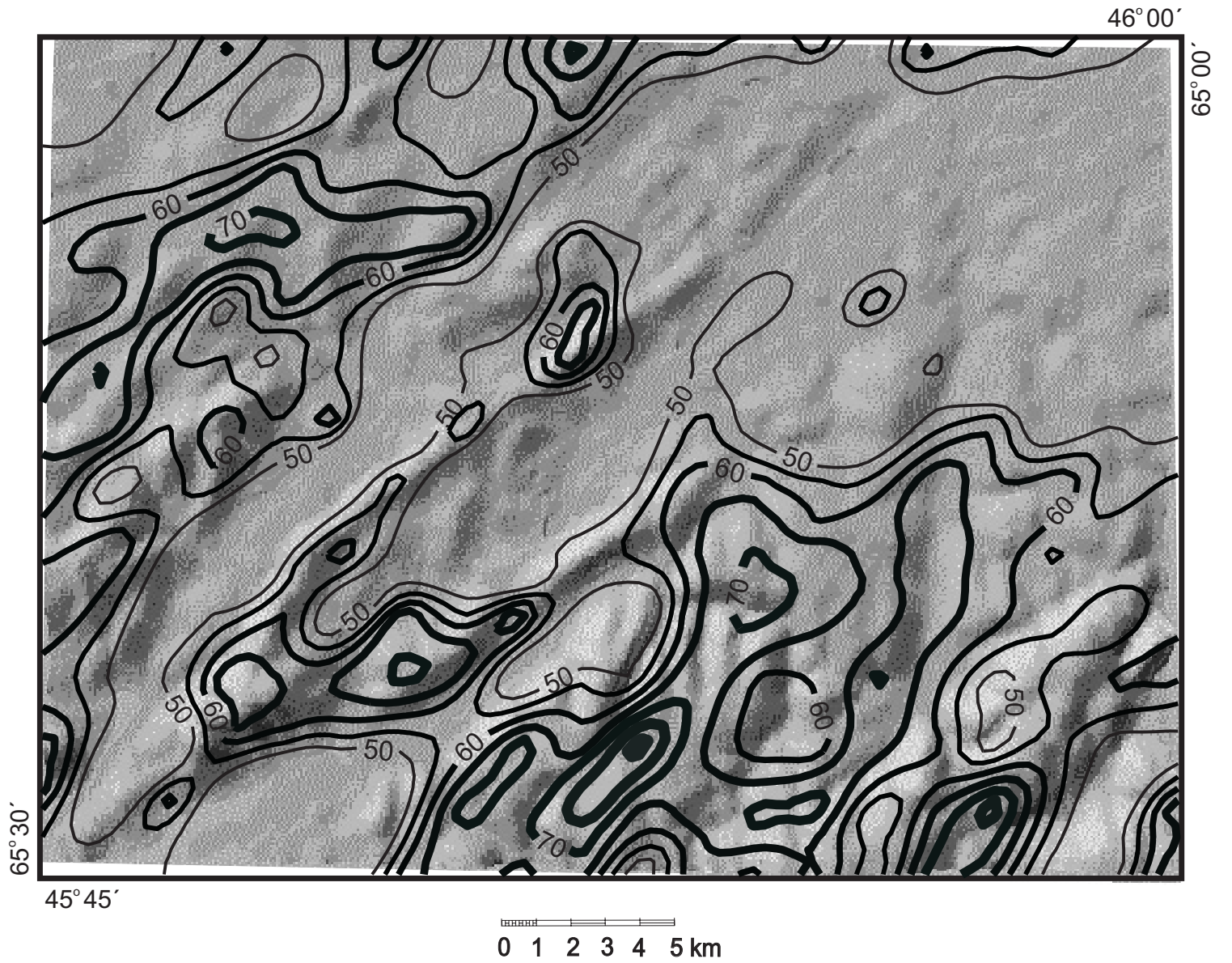

$46^{\circ} 00$

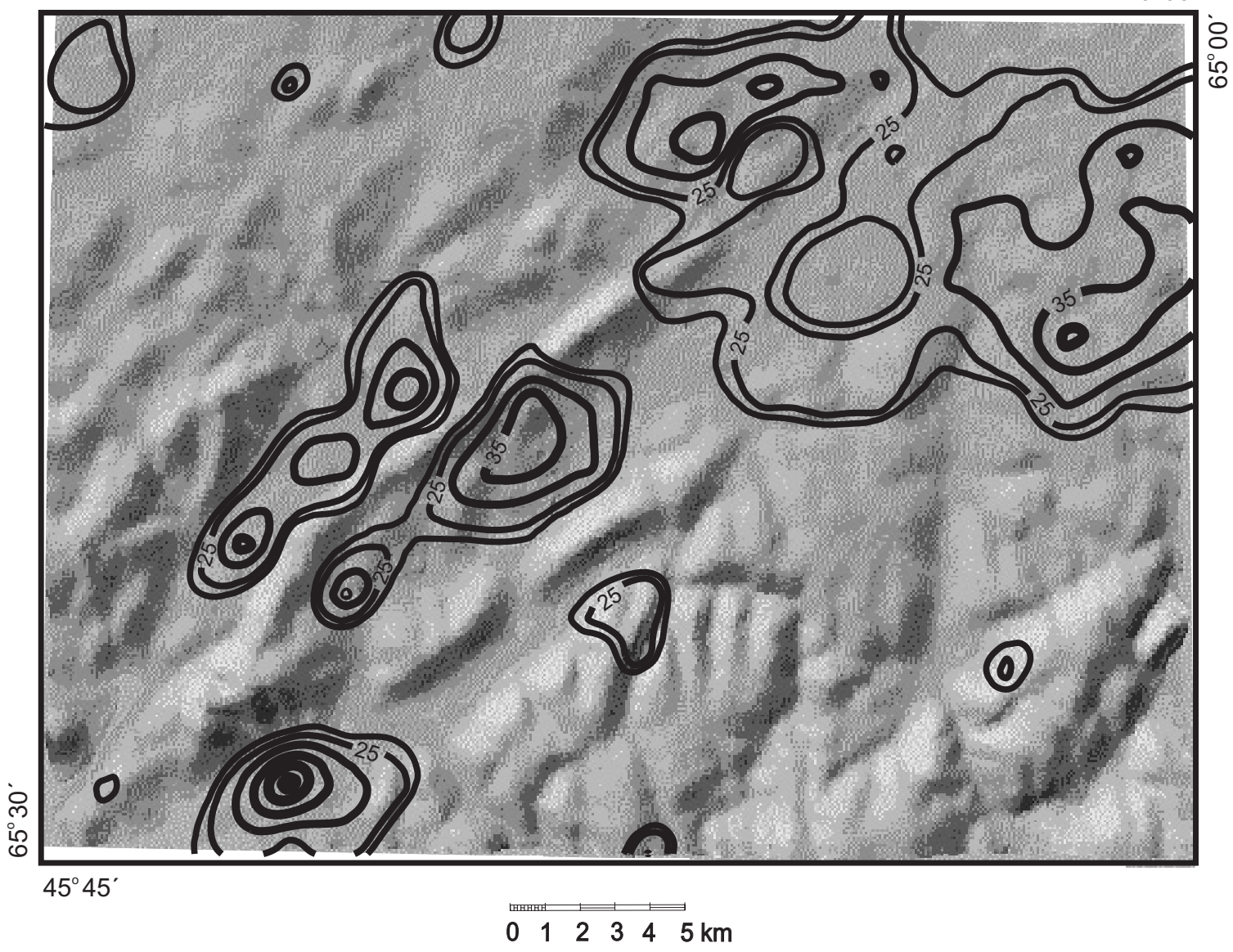


the mineralized zone on Jordan Mountain (mineral sites 1 and 2, Fig. 2). However, no dispersal of $\mathrm{Ca}$ or $\mathrm{Mg}$ was observed from the Windsor Group limestone and evaporites in the Havelock area. The absence of both clasts and matrix components from this unit suggests that these rocks were not eroded appreciably during glaciation.

The lithophile elements (Al, $\mathrm{Cr}, \mathrm{Na}, \mathrm{Sc}, \mathrm{Rb}, \mathrm{Th}$ ), best illustrated by Al (Fig. 10), demonstrate anomalous till concentrations in areas overlying Horton and Windsor group rocks and decline in concentration an east-southeastward direction in till over Cumberland Group bedrock. This pattern of distribution is mirrored by $\mathrm{Rb}$ and Th values (Allaby 2000). Aluminum content forms one of the longer dispersal patterns, extending from a point north of the Anagance Ridges, southeastward as a $10 \mathrm{~km}$ ribbon-shaped anomaly (Fig. 10).

Sodium distribution forms a broad linear pattern, $>10 \mathrm{~km}$ wide and extending over $25 \mathrm{~km}$ in a northeast-southwest direction (Fig. 11), occurring just west and parallel to the main ridge in the area (Fig. 4). This abrupt change in Na content may be due to the interference of the major down-ice ridge as the glacier flowed eastwardly across it. Additional anomalous concentrations of $\mathrm{Na}$ also occur in till overlying rocks of the Caledonia Zone in the southeast corner of the study area. A distribution similar to $\mathrm{Na}$ is found for $\mathrm{Mg}, \mathrm{Sc}, \mathrm{Sr}$, and $\mathrm{V}$, and to a lesser extent for some of the base metals $\mathrm{Cr}, \mathrm{Pb}$, and $\mathrm{Zn}$ (Allaby 2000).

A total of 10 chalcophile elements $(\mathrm{Ag}, \mathrm{As}, \mathrm{Bi}, \mathrm{Cd}, \mathrm{Cu}, \mathrm{Hg}$,
$\mathrm{Pb}, \mathrm{Sb}, \mathrm{Se}$, and $\mathrm{Zn}$ ) were examined for evidence of glacial dispersal. The pattern of Zn (Fig. 12) best demonstrates that these elements generally have short and irregular dispersal trains with elongation toward the east, northeast (similar to $\mathrm{Na}$, Fig. 11), southeast, and southwest. However, the northeasterly and southwesterly elongation of some patterns may be an artefact of the northeast-southwest trend of the local fault system, and not only a product of glacial dispersion. Elevated concentrations of As are associated with base metal occurrences at mineral sites 1 and 2 , between faults southeast of mineral site 6 (Fig. 2). High $\mathrm{Cu}$ and $\mathrm{Hg}$ concentrations were observed in till over the large composite intrusion in the Caledonia Zone and may be associated with the mineral occurrence near mineral site 7 (Fig. 2). High concentrations of Zn (Fig. 12) and Pb, occur similarly in irregularly shaped anomalies coincident with local fault systems and known mineral sites.

Aluminum showed strong correlation with $\mathrm{Sc}$ and moderate positive correlations with $\mathrm{Fe}$. The correlation between $\mathrm{Al}$ and $\mathrm{Fe}$ (0.608) is likely coincidental rather than indicative of secondary weathering, as these elements are not strongly correlative with other mobile elements (Table 1).

$\mathrm{Hg}$ and $\mathrm{Br}$ display a strong correlation (0.743), which may be attributed to the anomalous concentrations of both elements in the till overlying a large composite intrusion in the Caledonia Zone south of the Carboniferous / Hadrynian boundary (Fig. $2)$. Anomalous concentrations of $\mathrm{Cu}(>60 \mathrm{ppm})$ only occur in this area, forming a small area of dispersal directly over site 7 ,

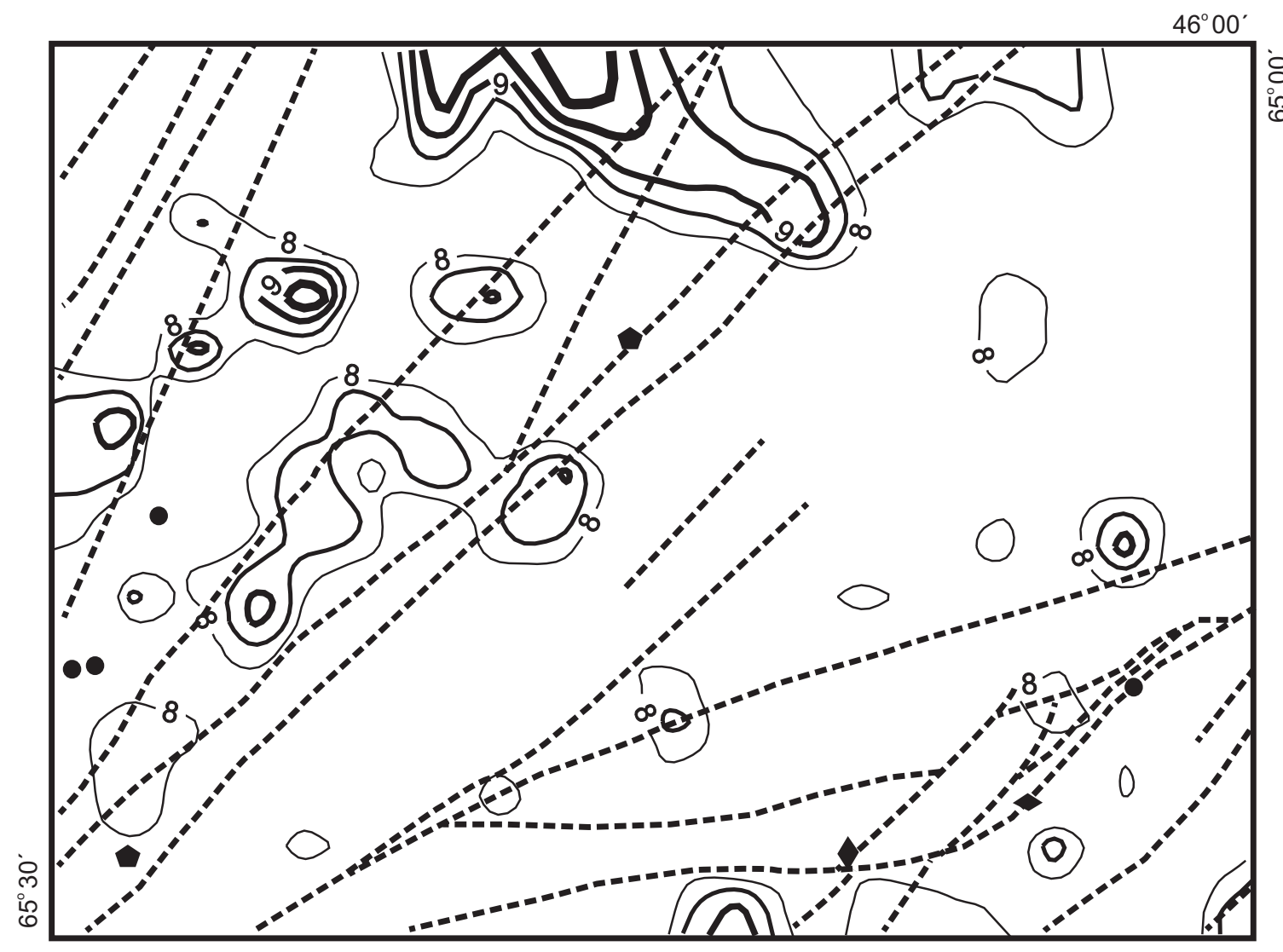

Fig. 10 Dispersal pattern for Al ppm content in till matrix. Known mineral occurrences are indicated by symbols explained in Fig. 2 and dashed lines represent major faults in the area. 
Fig. 11 Dispersal pattern for Na weight percent content in till matrix. Note major southwestward and northeastward elongation of dispersal pattern up ice of the largest ridge in the area (see Figure 3). Known mineral occurrences are indicated by symbols explained in Fig. 2 and dashed lines represent major faults in the area.

Fig. 12 Dispersal pattern for Zn ppm content in till matrix, with major concentrations displaced southeast of known mineral occurrences. Known mineral occurrences are indicated by symbols explained in Fig. 2 and dashed lines represent major faults in the area.

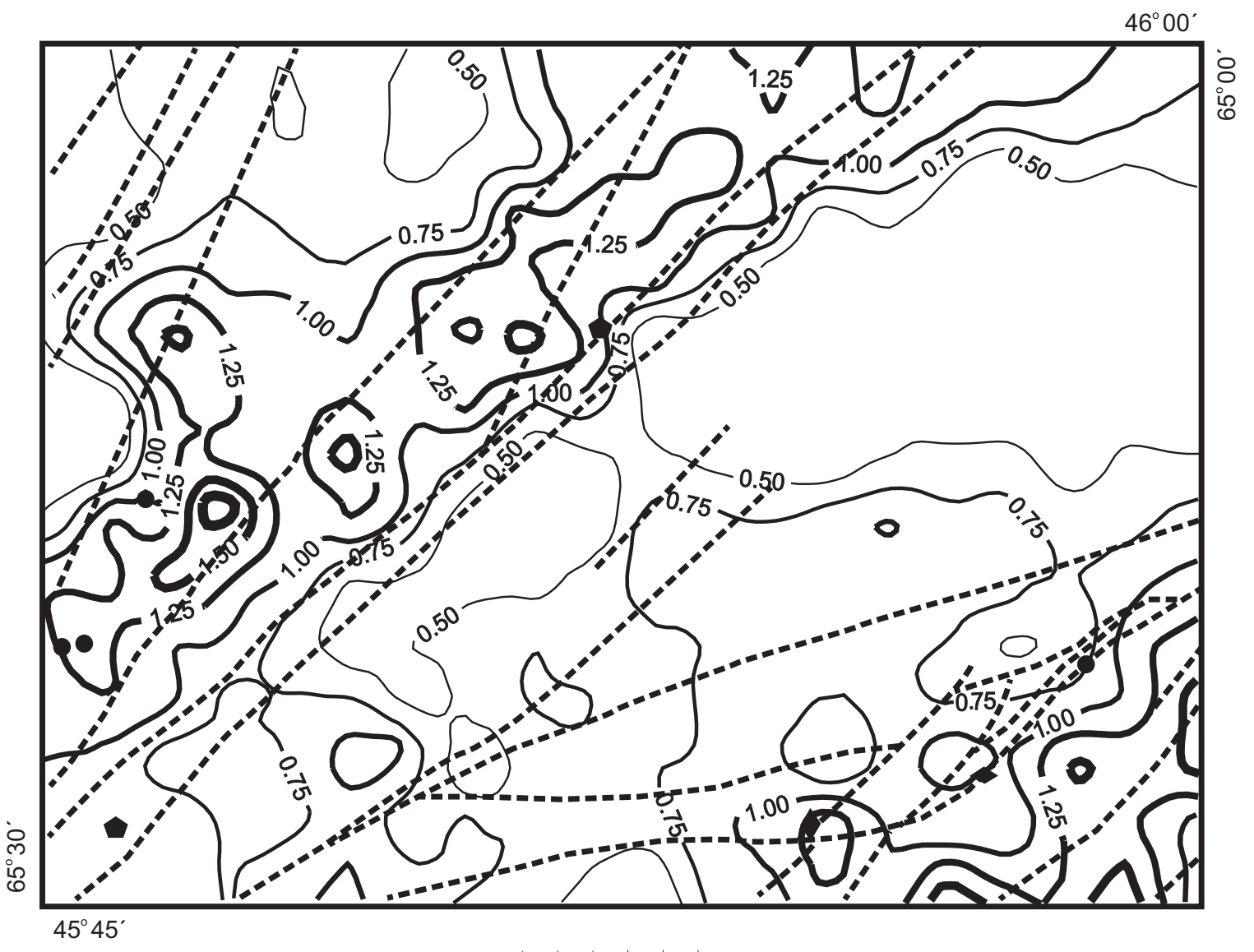

$\begin{array}{llllll}0 & 1 & 2 & 3 & 4 & \end{array}$

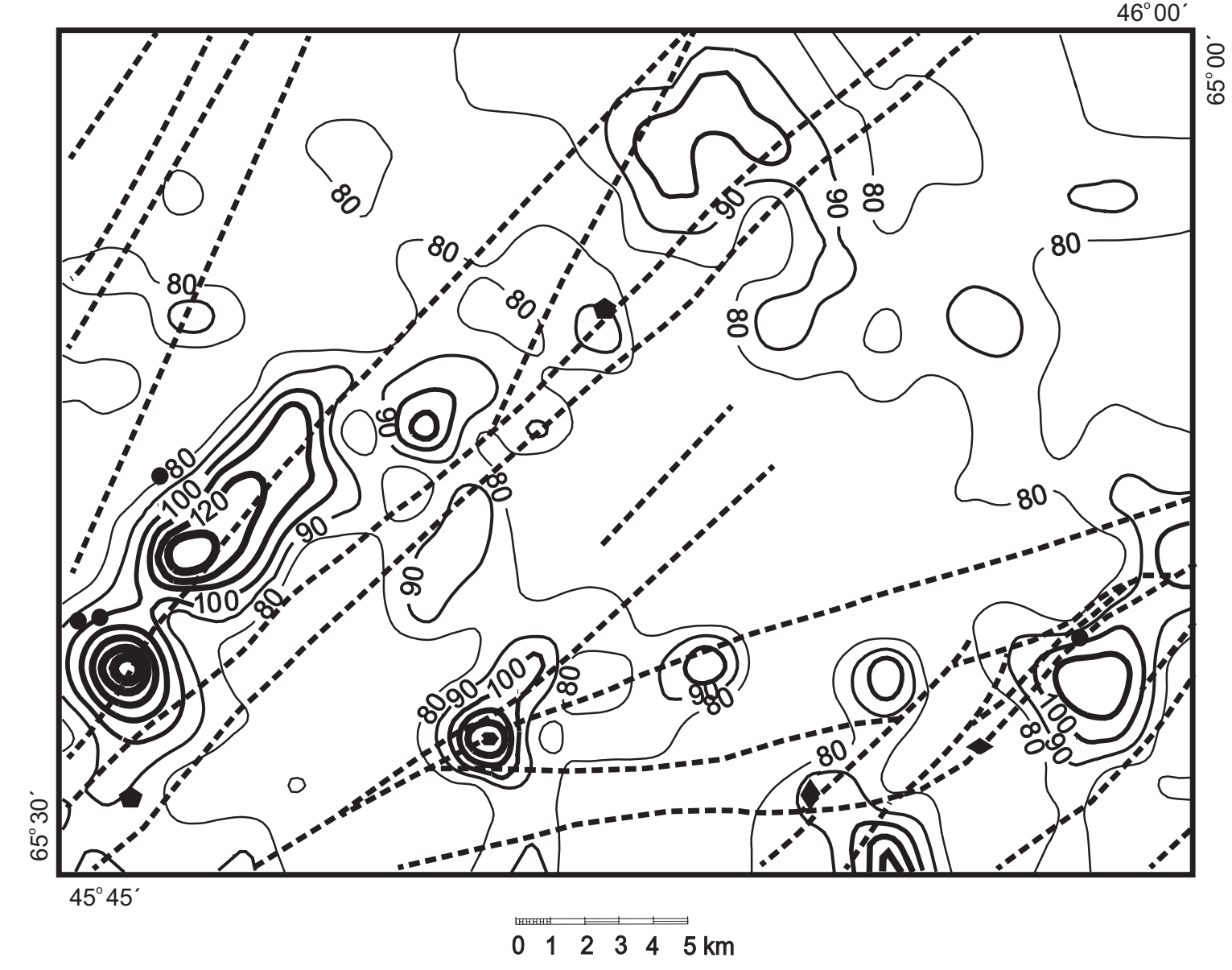


of about two kilometre wide and extending three kilometres southeastward (not shown).

Significant covariance with granulometric data is demonstrated only with the concentration of $\mathrm{Hg}$; positively with sand content (0.649) and negatively with clay content (-0.604). These correlations suggest that elevated $\mathrm{Hg}$ is associated with a mineral whose terminal grade lies predominantly in the sand-sized particle range (e.g. cinnabar), rather than simply an artefact of the geochemical analyses on the fine silt and clay fraction and their strong negative correlations with sand (Table 1). The anomalous $\mathrm{Hg}$ concentrations (>100 ppm) were found only in till overlying composite intrusions southward of the Carboniferous / Hadrynian boundary (Fig. 2).

Similarly reported by Munn et al. (1996) for the adjoining map sheet south of the study area, the highest elemental correlations occur amongst the lanthanide elements. Particularly between La and Sm (0.840), La with Ce (0.800), Sm with Ce (0.789), and $\mathrm{Sm}$ with $\mathrm{Eu}(0.719)$ and lesser correlations between these elements and $\mathrm{Nd}, \mathrm{Eu}, \mathrm{Yb}, \mathrm{Y}, \mathrm{Lu}$ (see Table 1). Lithophile and rare earth elements have been found to be occasionally elevated slightly in ablation till (Stumpf et al. 1997), but this is not believed to be the cause here. Two areas of commonality identified for most of these elements are indicated by Sm dispersal (Fig.13) and were found to be: (a) the area of mineral sites 1 and 2 (Fig. 2); and (b) sample site H12 (Fig. 3) an area between the intersection of two faults. This latter location also contained anomalous till matrix concentrations for $\mathrm{As}, \mathrm{Co}, \mathrm{Cr}$,
$\mathrm{Ni}, \mathrm{Zn}$, and $\mathrm{Rb}$, which may account for some correlation among these elements.

Of the alkali metals, $\mathrm{Na}$ correlates strongly with $\mathrm{Sr}(0.744)$ and $\mathrm{Rb}$ displays a strong correlation with $\mathrm{K}(0.758)$ and slightly less $(0.635)$ with Cs. Of the transition metals, Sc exhibits strong correlations with $\mathrm{V}(0.743)$ and $\mathrm{Fe}(0.727)$. Positive correlations between these elements and $\mathrm{Al}, \mathrm{Co}, \mathrm{Cu}$, and $\mathrm{Ni}$ are likely due to their association with $\mathrm{Fe}$ and coincidental anomalous occurrences rather than solely from reactions with organic matter during diagenesis of sedimentary rocks. However, the latter may be indicated in some units: for example, coincidental point-source anomalies of $\mathrm{Cu}$ and $\mathrm{Al}$ occur only in the area south of mineral site 7 (sample site T12, Fig. 3). Coincidental point source anomalies for $\mathrm{Ni}$ and $\mathrm{Co}$ occur at mineral site 6 and over faults (sample sites, Q13, H12, P2, Fig. 3). Anomalous concentrations of Zn also occur at these sites (Fig. 12) but, as Zn is relatively more abundant and likely originates from several sources; Spearman correlations between these elements are weak (Table 1).

\section{DISCUSSION AND CONCLUSIONS}

Till composition is closely related to its bedrock source (Dreimanis 1976). As a "first derivative" sediment, till is derived from bedrock, comminuted, and deposited directly by ice (Shilts1976). Thus for tills, geochemical and clast dispersal

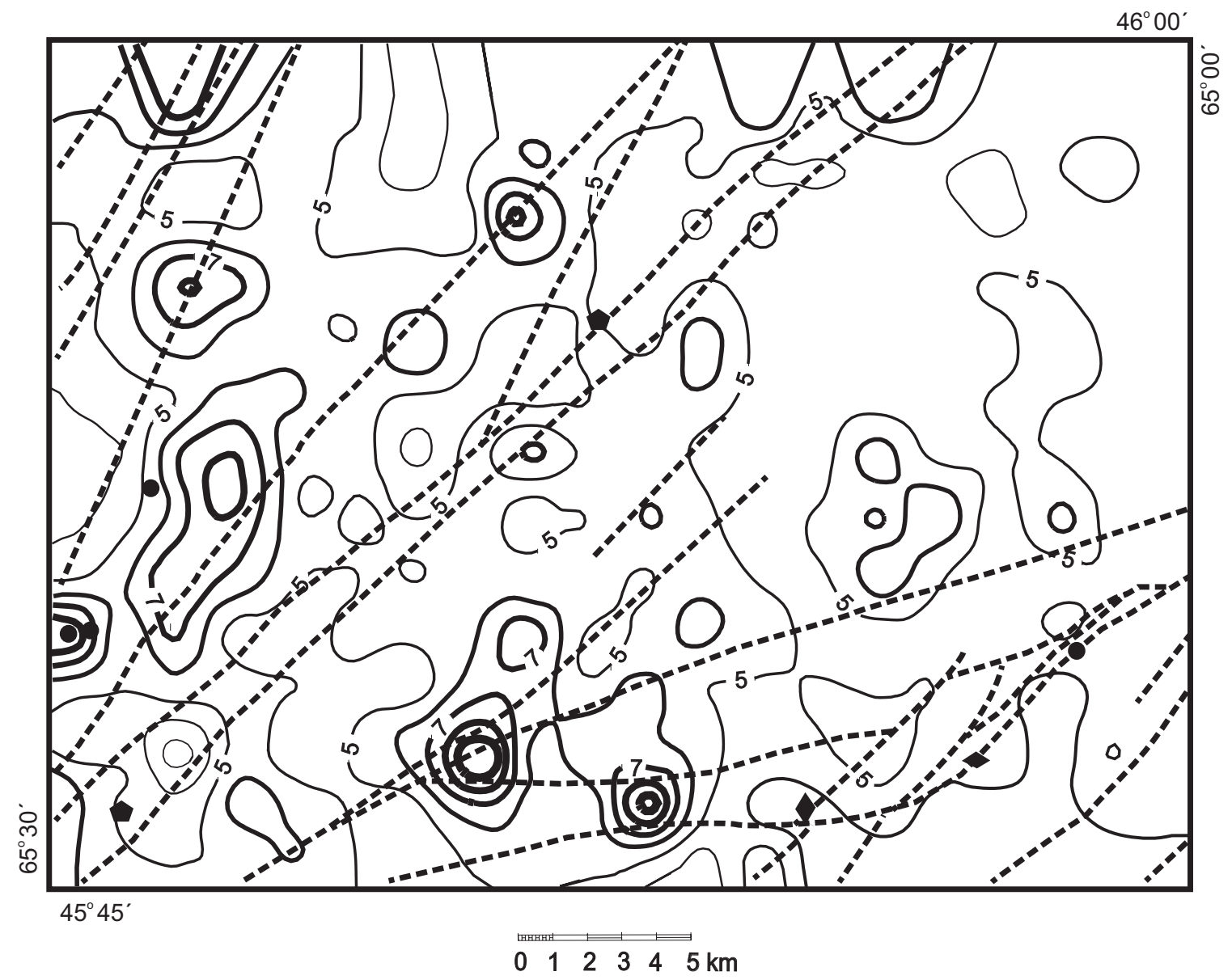

Fig. 13 Dispersal pattern for Sm ppm content in till matrix (dispersal was similar for Lu and $\mathrm{Yb}$; Allaby 2000), with known mineral occurrences as explained in Fig. 2 and major faults (dashed lines) from Fig. 2. 
patterns (dispersal trains, plumes or fans) commonly reflect the directions of ice movement, providing a clear indication of ice-flow direction. Glacier incorporation of distinctive materials results in anomalous concentrations in all size fractions of the glacial load because of size-reduction during transport of eroded clasts. Dispersal patterns are recognized by contouring concentrations of such components, which decrease in abundance down glacier of the source, or 'head' of the dispersal pattern (e.g. Dreimanis 1958; Shilts 1976; Coker and DiLabio 1989; Broster and Huntley 1995). The nature of the dispersal pattern is less clear when the resulting till has been deposited shortly after changes in glacier dynamics, with variation in topography or underlying material, or where the glacier is not in erosive equilibrium with the bedrock (e.g. where bedrock is covered by thick deposits of sediment).

For the study area, only one stratigraphic till unit was observed and the direction of ice movement is inferred mainly from striae sites and the areal distribution of till constituents (Dreimanis and Vagners 1971; Shilts 1976; Broster 1986; Clark 1987; Broster and Seaman 1991). Glacial dispersal patterns of all lithologies in the study area indicate that the clasts are locally derived, a common characteristic of tills in New Brunswick (Balzer and Broster 1994; Munn et al.1996; Stumpf et al. 1997). Lithologic concentrations in till clasts are highest near their known bedrock source and decrease rapidly in a down-ice direction. Clast trains rarely exceed $12 \mathrm{~km}$ in length and trains with multiple "heads" suggest additional sources for some lithologies. For example, the occurrences of granite erratics in the northern part of the area (Fig. 6) and of felsic volcanic clasts found northeast of their known source (Fig. 7), do not apparently conform to the idealized model of a glacial dispersal train, i.e. one that is elongated down glacier from a single source (Shilts 1976; Coker and DiLabio 1989). This is probably due to the occurrence of these lithologies as clasts in the underlying conglomerate units, discussed previously by Broster et al. (1997).

Klassen (2001) noted that the distinction of glacial dispersal concentration patterns depends on the physical and geochemical properties of the indicator, glacial process (e.g. ice dynamics), and the size fraction chosen for study. Dreimanis and Vagners (1971) suggested that the matrix-sized fraction of till is produced at the expense of the clast-sized fraction through the process of glacial comminution. However, for the study area, the Spearman's multivariate analysis demonstrates no significant correlation between the clast and matrix composition in the till. This suggests that some areas may have experienced preferential erosion due to differences in bedrock strength, discontinuities, aspect, and permeability (Broster and Seaman 1991), topographic obstructions (Hornibrook et al. 1991; Balzer and Broster 1994; Stumpf et al. 1997), changes in ice temperature as in the case of cold ice induced fracture and thrusting versus warm ice induced sliding and abrasion (Broster 1991; Broster and Seaman 1991), or that sediments were entrained in sufficient quantities to confuse correlations (Broster 1982).

Till is often composed of sediments that have undergone extensive dilution from multiple episodes of transport and redeposition, which contributes to a poor correlation between matrix and clast content (Broster 1982). The low abundance of clasts from sedimentary rock units in till overlying the western half of the study area can be interpreted as evidence that the glacier was not a powerful agent of bedrock erosion locally. This conclusion is further substantiated by the poor agreement between the granulometric data and the underlying sedimentary bedrock units in this region (Figs. 2, 8, 9), which implies that the till matrix is not composed of material derived only from glacial erosion of underlying bedrock. Therefore it is likely that the basal sediment load did not establish an erosive equilibrium with the underlying bedrock for the till in parts of the study area.

The strong inverse correlation between sand and clay (Table 1) is probably a reflection of the differences in glacial dynamics and incorporation. Sand content is noticeably higher at, and immediately down ice of, the major topographic ridges. This likely reflects increased erosion and incorporation as the glacier climbed over these obstacles, particularly the Anagance Ridges and Central Plateau, which are oriented transverse to the regional flow direction. The locations of higher clay content in the till is coincident with low-lying areas (Figs. 4,9) and likely reflects incorporation of sediments occupying the valleys at the time of glacier advance.

Generally, geochemical dispersal trains are about $5 \mathrm{~km}$ long and irregularly shaped. The heads or maximum concentrations of dispersal trains often correspond with known mineral occurrences, geochemically unique bedrock units, or structural trends. Deviation in the elongation of a dispersal fan is more likely due to changes in flow direction and onset of ice streaming (e.g. Stea and Finck 2001) rather than palimpsest fans (Parent et al. 1996) from reworking or reorientation of deposited till. Also, increased shearing and incorporation at topographic obstructions often result in longer dispersal trains (Hornibrook et al. 1991; Balzer and Broster 1994).

Till geochemical anomalies overlying faults may be indicative of local zones of mineralization if these faults acted as conduits for hydrothermal activity, a mechanism suggested by St. Peter (1992) for the origin of some known copper anomalies (e.g. site 6, Fig. 2). This scenario was best demonstrated by Zn and Sm (Figs. 12, 13) and also occurred for several other elements, including $\mathrm{Au}, \mathrm{Ba}, \mathrm{Cr}, \mathrm{Ni}, \mathrm{Pb}$, Th and $\mathrm{Y}$ (Allaby 2000). All three mineral sites in the Caledonia Zone (Fig. 2, Sites 6, 7, 8) show anomalous concentrations of $\mathrm{Hg}, \mathrm{Cu}, \mathrm{Pb}$, or $\mathrm{Zn}$ in the overlying till.

In the western half of the map area, dispersal trains for $\mathrm{Na}$ and Sm (Figs. 11, 13) form ribbon-shaped concentration patterns that are elongated south-southwestward along the western side of the Anagance Ridges. In the north-central section of the study area, a $10 \mathrm{~km}$ long Al concentration pattern, located approximately $2 \mathrm{~km}$ northeast of the ridge, does not deviate significantly from its southeasterly trend and forms the longest geochemical dispersal pattern (Fig. 10). The Al dispersal within the glacier likely did not encounter any significant topographic features; therefore, it probably records 
the regional ice-movement direction (also recorded in striae to the west; Fig. 4). Southeastward flow is also seen for $\mathrm{Al}$ in the central area of Anagance Ridges and at that same location for Zn (Figs. 10,12), and for the distribution of sedimentary and felsic clasts (Figs. 5,7).

In the southeastern part of the study area, till clasts derived from sedimentary rock decrease in content toward the southeast (Fig. 5), inversely to clasts from granitic and felsic sources (Figs. 6, 7). Geochemical dispersal trains from known mineral occurrences, for example Zn (Fig. 12), are elongated toward the southeast.

Evidence for strong northward flowing ice across this area of the Central Plateau is not demonstrated by our data. In the eastern half of the study area, clast lithologies indicative of the Central Plateau are absent in till overlying the Moncton Subbasin. This further suggests that the Central Plateau was not extensively eroded by northward-moving ice. This conclusion is supported by Munn et al. (1996), who found no conclusive evidence of northward ice flow in the Waterford map area, located immediately south of the study area. The absence of evidence supporting a late northward flow event indicates that the late phase remnant ice cap on the Caledonian Highlands, as proposed by Chalmers (1890) and Foisy and Prichonnet (1991), did not affect the study area, nor was it very erosive.

\section{Ice-flow phases}

The Late Wisconsinan glacial history of the Petitcodiac map area can be divided into three ice-flow phases that account for the observations discussed here. These are informally discussed as: (a) phase 1, early glacial flow; (b) phase 2, glacial maximum; and (c) phase 3, late glacial flow.

\section{Phase 1, early glacial flow}

Striae and dispersal patterns of till components indicate that glacier flow was diverted around the Anagance Ridges and Central Plateau. This likely occurred during the early phase of glaciation as the thin edge of the advancing ice sheet flowed southward and eastward into the region. This would explain striae indicating both northeast and southwest flow along the front of the Central Plateau at the southeast corner of the study area (Fig. 4) and the dispersal of till components around the Anagance Ridges. According to Rampton et al. (1984), glacial advance may have occurred at the onset of the Chignecto iceflow phase, approximately at $18 \mathrm{ka}$.

\section{Phase 2, glacial maximum}

During phase 2, ice became sufficiently thick to override the Anagance Ridges and Central Plateau and establish a regional ice-flow pattern that varied between south-southwestward to south-southeastward over the entire area. It is possible that this reflects the combined influence of ice growth of the Gaspereau and Escuminac ice centres. This may have occurred during the Chignecto phase of Rampton et al.(1984), approximately 15 to
$18 \mathrm{ka}$. Most of the glacial dispersal across the Central Plateau occurred during this phase.

\section{Phase 3, late glacial flow}

Near the conclusion of the Chignecto phase, at approximately 13.5-14 ka, sea level began to rise, marking the retreat of the Escuminac ice centre (Rampton et al. 1984). Glacier ice began flowing toward major outlets and calving bays, northeastward toward the Gulf of St. Lawrence and southward into the Bay of Fundy. When the ice sheet became too thin $(<500$ $\mathrm{m}$ ) to override the Central Plateau, an ice-flow divide developed as ice streamed around its northwestern slope. Increased calving and drawdown of the ice sheet may have began pulling ice around the Central Plateau and into the Bay of Fundy (Fig. 1). The ice-flow divide would have separated ice moving southsouthwestward from ice moving northeast around the northern end of the plateau, toward the outlet valley at Moncton.

Glaciofluvial ice-contact stratified drift and ablation moraine are limited mainly to valleys, indicating that ice lobes remained in the area during deglaciation, with rapid flow and melting (of the ice sheet) facilitated by sea-water flooding of low-lying valleys. Deglaciation likely proceeded slowly under active ice conditions to provide sufficient time for the welldefined east-southeast to east-northeastward-trending glacial dispersal trains to develop. Eastward dispersal and valley melting support the ice-flow model proposed by Prest (1970), Stea (1984), Stea and Mott (1989), and Stea et al. (1998), suggesting a slow glacial retreat during deglaciation in the Bay of Fundy region, with approximately $40 \mathrm{~m}$ of isostatic rebound in the Petitcodiac area and 20 to $30 \mathrm{~m}$ in the Moncton area. Due to delayed crustal isostatic re-equilibration, significant encroachment of the sea accompanied deglaciation (Stea $e t$ al. 1998). The gradual encroachment of the sea probably accelerated the calving rates in outlet valleys, likely increasing ice-flow velocities.

\section{Implications for models of glacial dispersal}

Drift prospecting employs the examination of the areal distribution of anomalous clast or matrix components of a till for the delineation of buried mineral sources, expected to be at or near the point of highest concentration. When drawn on a map the dispersal pattern can form a variety of shapes that reflect the size of the source unit and approximate distance of transport. Mathematical techniques can also be used to quantify the transport distance and reduction in glacial load. For example, half-distance length (Gillberg 1967; Bouchard and Salonen 1989) and the empirical exponential decay relationship between distance and load, based on the change in concentration between local and distal components, are discussed by Klassen (2001), and by Stea and Finck (2001). However, entrainment, erosion, mixing and transport (and thus, the dispersal pattern) are affected by several factors, including: (1) grain size fraction and volume of sample investigated; (2) lithology and relative mineral hardness; (3) characteristics of 
the source unit (e.g. attitude and size of outcrop, both related to the amount of erosion); (4) inheritance, overprinting and dilution of load; (5) glacial dynamics (e.g. basal thermal conditions, velocity and flow direction, centres of ice-growth); (6) erosional and depositional history of the till fraction; (7) local subglacial topography; and (8) the degree of variation of the preceding factors (Dreimanis and Vagners 1971; Shilts 1976; Broster 1986; Hornibrook et al. 1991; Balzer and Broster 1994; Broster and Huntley 1995; Broster et al. 1997; Stumpf et al. 2000; Klassen 2001; Stea and Finck 2001).

The results discussed here indicate that dispersal models are prone to errors when applied to areas of rugged terrain where a glacier has crossed a valley or ridge and at locations containing large deposits of fine-grained sediments. This occurs because the shape and size of a dispersal pattern and the precision of empirical models for estimates of glacial dispersal distance are affected by such conditions. Undulating topography results in change between compressive and transgressive flow and stacking or mixing of englacial debris (Broster 1986). Increased friction and shearing as a glacier flows over a topographic obstruction increases erosion, comminution, mixing, and thus dilution of the glacier load. Extensive englacial mixing of the glacier load would result in tills of compositional uniformity from top to bottom. This may be why researchers often report compositional similarity between ablation and basal tills for many areas of New Brunswick (e.g. Broster and Seaman 1991). In rugged areas where topographic undulations are frequent, till composition would be "immature" (Dreimanis and Vagners 1971), well mixed, and biased toward the lithologies comprising the topographic obstruction.

In the study area, till deposited down ice of topographic obstructions, demonstrate dilution to clast and matrix content with major increases in sand and clast size fractions and minor changes to till geochemical composition. Down ice of valleys the fine fraction of the till matrix is increased relative to the clast fraction, diluting and overprinting till geochemistry (Broster 1986). Thus, as the sediment accumulations at these locations are often second or third derivatives (Shilts1976), geochemistry of a till deposited down ice of valleys or along coasts may be unrelated to local bedrock.

\section{ACKNOWLEDGEMENTS}

Funding was provided by the Geological Surveys Branch of the New Brunswick Department of Natural Resources and Energy (NBDNRE). Sample collection and geochemical analyses were funded by NBDNRE operating budgets to A. Pronk and Research Contracts to B. Broster. Some of the data presented here represents part of a UNB graduate project by G. Allaby. The authors are grateful to R. Boldon for field assistance and sample preparation and to $S$. Allard for improvements to figures. We also thank the journal-appointed referees, N. Catto, M. Parkhill and co-editor R. Fensome for constructive comments that improved the manuscript.

\section{REFERENCES}

Aalund, H., \& Wicklund, R.E. 1950. Soil survey report of southeastern New Brunswick. Third Report of the New Brunswick Soil Survey, Dominion Department of Agriculture, $108 \mathrm{p}$.

Allaby, G.M. 2000. Till provenance and glacial history of Petitcodiac (NTS $21 \mathrm{H} / 14$ ) map area, southeastern New Brunswick. Unpublished M.Sc. thesis, University of New Brunswick, $217 \mathrm{p}$.

BALZER, S.A., \& BROSTER, B.E. 1994. Comparison of clast and matrix dispersal in till: Canterbury area, New Brunswick. Atlantic Geology, 30, pp. 9-17.

BARR, S.M., \& WhITE, C.E. 1988. Field relations, petrology, and age of the northeastern Point Wolf River pluton and associated metavolcanic and metasedimentary rocks, eastern Caledonia Highlands, New Brunswick. In Current Research, Part B, Geological Survey of Canada, Paper 881B, pp. 55-67.

Bоsтоск, H.S. 1970. Physiographic subdivisions of Canada. In Geology and economic minerals of Canada. Edited by R.J.W. Douglas. Geological Survey of Canada, Economic Geology Report 1, pp. 10-42.

Bouchard, M.A., \& Salonen, V.-P. 1989. Glacial Dispersal of boulders in the James Bay lowlands of Québec, Canada. Boreas, 18, pp. 189-199.

Bouyoucos, G.J. 1962. Hydrometer method improved for making particle size analysis of soils. Agronomy Journal, 54, pp. 464-465.

Broster, B.E. 1982. Compositional variations in the St. Joseph till units of the Goderich area, Ontario. Unpublished Ph.D thesis, University of Western Ontario, London, Ontario, $103 \mathrm{p}$.

BRoster, B.E. 1986. Till variability and compositional stratification: examples from the Port Huron lobe. Canadian Journal of Earth Sciences, 23, pp. 1823-1841.

BRoster, B.E. 1991. Glaciotectonic deformation in sediment and bedrock, Hat Creek, British Columbia. Géographic physique et quaternaire, 45 , pp. 5-20.

Broster, B.E., \& Huntley, D.H. 1995. Effective low-cost reconnaissance drift prospecting in areas of variable terrain: an example from the south-east Taseko Lakes area, central British Columbia. In Drift exploration in the Canadian Cordillera. Edited by P.T. Bobrowsky, A.J. Sibbick, J.M. Newell $\&$ P.F. Matysek. British Columbia Ministry of Energy, Mines and Petroleum Resources, Paper 1995-2, pp. 121-126.

Broster B.E., \& SeAman, A.A. 1991. Glacigenic rafting of weathered granite: Charlie Lake, New Brunswick. Canadian Journal of Earth Sciences, 28, pp. 649-654.

Broster, B.E, MunN, M.D., \& Pronk, A.G. 1997. Inferences on glacial flow from till clast dispersal, Waterford area, New Brunswick. Géographie physique et quaternaire, 51, pp. 29-39.

CHALmers, R. 1890. Surface geology of southern New Brunswick. Geological Survey of Canada, Summary Report 1889, 4, Part N, 92p. 
Chalmers, R. 1895. Report on the surface geology of eastern New Brunswick, northwestern Nova Scotia and a portion of Prince Edward Island. Geological Survey of Canada, Annual Report 1894, 7, Part M, 135 p.

Clark, P.U. 1987. Subglacial sediment dispersal and till composition. Journal of Geology, 95, pp. 527-541.

Coker, W.B., \& DiLabio, R.N.W. 1989. Geochemical exploration in glaciated terrain: geochemical responses. In Proceedings of Exploration '87: Third decennial international conference on geochemical exploration for minerals and groundwater. Edited by G. D. Garland. Ontario Geological Survey, Special Volume 3, pp. 336-383.

Dreimanis, A. 1958. Tracing ore boulders as a prospecting method in Canada. Canadian Mining and Metallurgical Transactions, 61, pp. 49-56.

DreIMANIs, A. 1976. Tills: their origin and properties. In Glacial till: an interdisciplinary study. Edited by R. F. Legget. Royal Society of Canada Special Publications, Ottawa, 12, pp. 11-49.

Dreimanis, A., \& Vagners, U.J. 1971. Bimodal distribution of rock and mineral fragments in basal tills. In Till: a symposium. Edited by R.P. Goldthwait. Ohio State University Press, pp. 237-250.

Foisy, M., \& Prichonnet, G. 1991. A reconstruction of glacial events in southeastern New Brunswick. Canadian Journal of Earth Sciences, 28, pp. 1594-1612.

GillberG, G. 1967. Further discussion of the lithological homogeneity of till. Geologiska Foreningens I Stockholm Förhandlingar, 89, pp. 29-49.

GrANT, D. 1977. Glacial style and ice limits, the Quaternary stratigraphic record, and changes of land and ocean level in the Atlantic Provinces, Canada. Géographie physique et quaternaire, 31, pp. 247-260.

Hawkes, H.E., \& Webb, J.S. 1962. Geochemistry in Mineral Exploration. Harper and Row Publishers, Incorporated, New York, $415 \mathrm{p}$.

Hornibrook, E.R.C., Broster, B.E., Gardner, W.W., \& Pronk, A.G. 1991. Glacial dispersal of heavy minerals in the late Wisconsinan till, central New Brunswick. Atlantic Geology, 27, pp. 199-208.

Hughes, T., Borns, H.W. JR., Fastook, J.L., Hyland, M.R., Kite, J.S., \& Lowell, T.V. 1985. Models of glacial reconstruction and deglaciation applied to Maritime Canada and New England. In Late Pleistocene history of the northeastern New England and adjacent Québec. Edited By H.W. Borns, Jr., P. LaSalle, and W.B. Thompson, Geological Society of America, Special Paper 197, pp. 139-150.

KLASSEN, R.A.A. 2001. Quaternary geological perspective on geochemical exploration in glaciated terrain. In Drift Exploration in Glaciated Terrain, Edited by M.B. McClenaghan, P.T. Bobrowsky, G.E.M. Hall, and S.J. Cook, Geological Society of London, Special Publications, 185, pp. 1-17.

McLeod, M.J., Johnson, S.C., \& Ruitenberg, A.A. 1994. Geological map of southeastern New Brunswick. New Brunswick Department of Natural Resources and Energy, Mineral Resources Division, Map NR-6. Scale 1:250 000.
MerLINI, S. (compiler) 1998. New Brunswick computerized mineral occurrence database (revised 1998). New Brunswick Department of Natural Resources and Energy, Minerals and Energy Division, Open File 98-21, digital mineral occurrence files.

Munn, M.D., Broster, B.E., \& Pronk A.G. 1996. Geochemical dispersion in till: Waterford area, New Brunswick. Atlantic Geology, 32, pp. 269-279.

Parent, M., Paradis, S., \& Doiron, A. 1996. Palimpsest glacial dispersal trains and their significance to drift prospecting. Journal of Geochemical Exploration, 56, pp. 123-140.

Prest, V. 1970. Quaternary geology of Canada. In Geology and economic minerals of Canada, Edited by R.J.W. Douglas. Geologic Survey of Canada, Economic Geology Report 1, pp. 676-764.

Pronk, A.G., Bobrowsky, P.T., \& Parkhill, M.A. 1989. An interpretation of Late Quaternary glacial flow indicators in the Baie Des Chaleurs region, northern New Brunswick. Géographie physique et quaternaire, 43, pp. 179-190.

Rampton, V.N., \& Paradis, S. 1981. Quaternary geology of Amherst map area $(21 \mathrm{H})$, New Brunswick. New Brunswick Department of Natural Resources, Mineral Development Branch, Map Report 81-3, 36 p.

Rampton, V.N., Gauthier, R.C., Thibault, J., \& Seaman, A.A. 1984. Quaternary geology of New Brunswick. Geological Survey of Canada, Memoir 416, $77 \mathrm{p}$.

RAPPOL, M. 1989. Glacial history and stratigraphy of northwestern New Brunswick. Géographie physique et quaternaire, 43, pp. 191-206.

Ruitenberg, A.A., Giles, P.S., Venugopal, D.V., Buttimer, S.M., Mccutcheon, S.R., \& Chandra, J. 1979. Geology and mineral deposits, Caledonia area. New Brunswick Department of Natural Resources, Memoir 1, 213 p.

Rose, D., \& Johnson, S.C. 1990. New Brunswick computerized mineral occurrence database. New Brunswick Department of Natural Resources and Energy, Mineral and Energy Division, Mineral Resources Report 3, 69 p.

SeAman, A.A. 1987. Granular aggregate resources Petitcodiac (NTS 21 H/14) map area, New Brunswick. New Brunswick Department of Natural Resources and Energy, Mineral Resources Division, Open File Report 87-1, 98 p.

SeAman, A.A. 1989. Glacial striae trends in New Brunswick: a compilation. New Brunswick Department of Natural Resources and Energy, Mineral Resources Division, Open File Report 89-34, $136 \mathrm{p}$.

SeAman, A.A. 1991. Complex glacial ice-flow events in New Brunswick with particular reference to the Oromocto Lake area, and implications for drift prospecting. New Brunswick Department of Natural Resources and Energy, Mineral Resources Division, Open File Report 82-6, 48 p.

Seaman, A.A. 1992. Till geochemistry of the Forest City (NTS 21 G/12) map area, York County, New Brunswick. New Brunswick Department of Natural Resources and Energy, Mineral Resources Division, Open File Report 92-6, 192 p. SHILTs, W.W. 1976. Glacial till and mineral exploration. In Gla- 
cial till, an inter-disciplinary study. Edited by R. F. Legget. Royal Society of Canada Special publications, Ottawa, 12, pp. 205-224.

Silk, J. 1979. Statistical Concepts in Geography. George Allen and Unwin, London, $256 \mathrm{p}$.

STEA, R.R. 1984. The sequence of glacial movements in northern mainland Nova Scotia determined through mapping and till provenance studies. In Correlation of Quaternary Chronologies. Edited by W.C. Mahaney. Geo Books, Norwich, England, pp. 279-297.

STEA, R.R., \& FINCK, P.W. 2001. An evolutionary model of glacial dispersal and till genesis in Maritime Canada. In Drift exploration in glaciated terrain. Edited by M.B. McClenaghan, P.T. Bobrowsky, G.E.M. Hall, and S.J. Cook. Geological Society of London, Special Publications, 185, pp. 237-265.

StEA, R.R., \& Mотт, R.J. 1989. Deglaciation environments and evidence for glaciers of Younger Dryas age in Nova Scotia, Canada. Boreas, 18, pp. 169-187.

Stea, R.R., Piper, D.J.W., FAder, G.J., \& Boyd. R. 1998. Wisconsinan glacial and sea level history of Maritime Canada and the adjacent continental shelf: a correlation of land and sea events. Geological Society of America Bulletin, 110, pp. 821-845.

St. Peter, C. 1992. Lithofacies, seismic facies, and strike-slip setting of the Lower Carboniferous alluvial/fluvial/lacustrine Albert Formation of New Brunswick. New Brunswick Department of Natural Resources and Energy, Mineral Resources Division, Open File Report 92-2, 145 p.

Stumpf, A.J., Broster, B.E., \& SeAman, A.A. 1997. Lithological and geochemical dispersal in till: McAdam area, New Brunswick. Atlantic Geology, 33, pp. 31-42.

StumpF, A.J., Broster, B.E., \& Levson, V.M. 2000. Multiple flow of the late Wisconsinan Cordilleran ice sheet in western Canada. Geological Society of America, 12, pp. 1850-1863.

van DE Poll, H.W. 1994. Carboniferous province and lithostratigraphy of the Chignecto Bay region, New Brunswick: a preliminary assessment. In Current Research 1993. Edited by S.A.A. Merlini. Department of Natural Resources and Energy, Minerals and Energy Division, Miscellaneous Report 12, pp. 188-201.

Editorial responsibility: Robert A. Fensome 